\title{
Stable nitrogen isotopic composition of amino acids reveals food web structure in stream ecosystems.
}

\section{$\operatorname{AUTHOR}(\mathrm{S})$ :}

Ishikawa, Naoto F; Kato, Yoshikazu; Togashi, Hiroyuki; Yoshimura, Mayumi; Yoshimizu, Chikage; Okuda, Noboru; Tayasu, Ichiro

\section{CITATION:}

Ishikawa, Naoto F ... [et al]. Stable nitrogen isotopic composition of amino acids reveals food web structure in stream ecosystems.. Oecologia 2014, 175(3): 911-922

\section{ISSUE DATE:}

2014-07

URL:

http://hdl.handle.net/2433/199595

\section{RIGHT:}

The final publication is available at Springer via http://dx.doi.org/10.1007/s00442-0142936-4.; This is not the published version. Please cite only the published version.; この論 文は出版社版でありません。引用の際には出版社版をご確認ご利用ください。 
Ishikawa et al. Amino acid $\delta^{15} \mathrm{~N}$ of stream animals

1

2 Stable nitrogen isotopic composition of amino acids reveals

\section{food web structure in stream ecosystems}

Naoto F. Ishikawa ${ }^{1,4^{*}}$, Yoshikazu Kato ${ }^{1}$, Hiroyuki Togashi ${ }^{2,5}$, Mayumi Yoshimura ${ }^{3}$, Chikage

Yoshimizu $^{1}$, Noboru Okuda ${ }^{1}$, Ichiro Tayasu ${ }^{1}$

${ }^{1}$ Center for Ecological Research, Kyoto University, 2-509-3 Hirano, Otsu, Shiga 520-2113, Japan

${ }^{2}$ Field Science Education and Research Center, Kyoto University, Oiwake-cho, Kitashirakawa, Sakyo, Kyoto 606-8502, Japan

${ }^{3}$ Kansai Research Center, Forestry and Forest Products Research Institute, 68 Nagaikyutaroh, Momoyama, Fushimi, Kyoto, 612-0855, Japan

${ }^{4}$ Present address: Japan Agency for Marine-Earth Science and Technology, 2-15

Natsushima-cho, Yokosuka, Kanagawa 237-0061, Japan

${ }^{5}$ Present address: Tohoku National Fisheries Research Institute, Fisheries Research Agency,

3-27-5, Shinhama-cho, Shiogama, Miyagi 985-0001, Japan

${ }^{*}$ Corresponding author.

E-mail: ishikawan@jamstec.go.jp

Running head: Amino acid $\delta^{15} \mathrm{~N}$ of stream animals 
Ishikawa et al. Amino acid $\delta^{15} \mathrm{~N}$ of stream animals

\section{Abstract}

The stable nitrogen isotopic composition of individual amino acids (SIAA) has recently been used to estimate trophic positions (TPs) of animals in several simple food chain systems. However, it is unknown whether the SIAA technique is applicable to more complex food web analysis. In this study we measured the SIAA of stream macroinvertebrates, fishes, and their potential food sources (periphyton and terrestrial C3 plant litter) collected from upper and lower sites in two streams having contrasting riparian landscapes. The stable nitrogen isotope ratios of glutamic acid and phenylalanine confirmed that for primary producers (periphyton and C3 litter) the TP was 1, and for primary consumers (e.g., mayfly and caddisfly larvae) was 2 . We built a two-source mixing model to estimate the relative contributions of aquatic and terrestrial sources to secondary and higher consumers (e.g., stonefly larva and fishes) prior to the TP calculation. The estimated TPs (2.3-3.5) roughly corresponded to their omnivorous and carnivorous feeding habits, respectively. We found that the SIAA method offers substantial advantages over traditional bulk methods for food web analysis because the SIAA method defines the food web structure based on the metabolic pathway of amino groups, and the SIAA method can be used to estimate food web structure under conditions where the bulk method cannot be used for the analysis. Our result provides evidence that the SIAA method is applicable to the analysis of complex food webs, where heterogeneous resources are mixed.

Key Words: periphyton; terrestrial C3 litter; aquatic invertebrate; fish; two-source mixing model; resource reliance; trophic position; compound-specific isotope analysis; nitrogen metabolism 
Ishikawa et al. Amino acid $\delta^{15} \mathrm{~N}$ of stream animals

\section{Introduction}

The biological production fuels energy dynamics through an ecosystem (Lindeman 1942) via the trophic pathways composed of the prey-predator relationships involving spatial and temporal variations (Winemiller 1990). In most freshwater (e.g., stream) ecosystems associated with terrestrial and/or ocean ecosystems, biological production is supported by in situ primary production (e.g., periphytic algae attached to a substrate) as well as organic materials derived from other sources (e.g., terrestrial leaf litter) and these determine food web structure (Hynes 1970; Fisher and Likens 1973; Vannote et al. 1980; Nakano and Murakami 2001). Aquatic invertebrates are diverse animal consumers in stream food webs: such as algal grazing specialists (e.g., Heptageniidae larva: mayfly), leaf shredding specialists (e.g., Lepidostomatidae larva: caddisfly), and predatory generalists (e.g., Perlidae larva: stonefly) (Cummins 1973; Takemon 2005). The resource reliance of animals implies dynamic flow of material and energy among ecosystems (Baxter et al. 2005; Carpenter et al. 2005). Animals that have multiple dietary pathways (so-called omnivore) often dominate communities and occupy non-integer trophic positions, suggesting that in natural trophic networks the prey-predator relationships form a tangled food web rather than a simple food chain (Marczak et al. 2007; Thompson et al. 2007).

Analyses of the stable carbon and nitrogen isotope ratios $\left(\delta^{13} \mathrm{C}\right.$ and $\delta^{15} \mathrm{~N}$, respectively) have contributed to the development of food web research during the last 30 years (e.g., Minagawa and Wada 1984; Fry 1991; Post et al. 2000). Animals’ bulk-tissue $\delta^{13} \mathrm{C}$ $\left(\delta^{13} \mathrm{C}_{\text {Bulk }}\right)$ and $\delta^{15} \mathrm{~N}\left(\delta^{15} \mathrm{~N}_{\text {Bulk }}\right)$ values have been used as indicators of food sources and trophic positions (TPs), respectively, because $\delta^{13} \mathrm{C}$ values can distinguish primary producers (e.g., aquatic algae vs. terrestrial plants: Deines 1980), and $\delta^{15} \mathrm{~N}$ values increase with higher TP (e.g., Vander Zanden and Rasmussen 2001; Post 2002). Therefore, biplots for $\delta^{13} \mathrm{C}_{\text {Bulk }}$ and 
Ishikawa et al. Amino acid $\delta^{15} \mathrm{~N}$ of stream animals

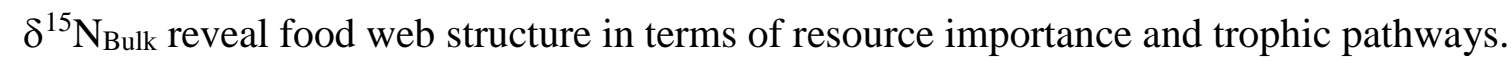

However, in the stream ecosystems the $\delta^{13} \mathrm{C}_{\mathrm{Bulk}}$ of periphytic algae (primary producers) is sometimes too variable to enable assessment of the food sources for animals (Ishikawa et al. 2012), and for $\delta^{15} \mathrm{~N}_{\text {Bulk }}$ the isotope enrichment factor per trophic level (TL) of stream invertebrates is likely smaller and more variable than that of other animals (Bunn et al. 2013). To better understand the food web structure in stream ecosystems, a novel technique enabling analysis of food sources and TPs will be indispensable.

Techniques for measurement of the stable nitrogen isotopic composition of amino acids (SIAA) have recently been developed and applied to estimating the TPs of various animals (e.g., McClelland and Montoya 2002; Popp et al. 2007; Miller et al. 2013). In amino acid metabolism, glutamic acid is subject to deamination and transamination, which leads to increased isotope enrichment per TL (trophic enrichment factor: TEF $=8.0 \%$ in $\delta^{15} \mathrm{~N}$ ). In contrast, phenylalanine remains its amino group during metabolism because animals cannot synthesize phenylalanine themselves, resulting in little isotope enrichment per TL (TEF = 0.4\% in $\delta^{15} \mathrm{~N}$ ) (Chikaraishi et al. 2009). The fairly constant TEFs in glutamic acid and phenylalanine have been observed in several systems, including feeding experiments performed by Chikaraishi et al. (2011) (quad-TLs: plant leaf > caterpillar and bee $>$ wasp > hornet) and Steffan et al. (2013) (penta-TLs: apple leaves > apple aphid > hover fly > parasitoid > hyperparasitoid). Therefore, the TP of an animal in a single food chain can be determined using the following simple equation, with small deviations in TP estimates $(1 \sigma \sim$ 0.2) (Chikaraishi et al. 2009):

$$
\mathrm{TP}=\frac{\delta^{15} \mathrm{~N}_{\mathrm{Glu}}-\delta^{15} \mathrm{~N}_{\mathrm{Phe}}+\beta}{8.0-0.4}+1
$$


Ishikawa et al. Amino acid $\delta^{15} \mathrm{~N}$ of stream animals

where $\delta^{15} \mathrm{~N}_{\text {Glu }}$ and $\delta^{15} \mathrm{~N}_{\text {Phe }}$ are the stable nitrogen isotope ratios of glutamic acid and phenylalanine of an animal, respectively. $\beta$ is the difference between $\delta^{15} \mathrm{~N}_{\text {Phe }}$ and $\delta^{15} \mathrm{~N}_{\text {Glu }}$ for a primary producer (baseline) in the food chain (i.e., -3.4 for aquatic autotrophs; +8.4 for terrestrial C3 plants; Chikaraishi et al. 2009; 2010a; 2011). Thus, in a single food chain the TP of an animal can be estimated only from its $\delta^{15} \mathrm{~N}_{\mathrm{Glu}}$ and $\delta^{15} \mathrm{~N}_{\text {Phe }}$ values, without the data on the

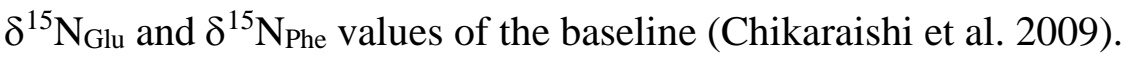

The applicability of the SIAA method to estimation of TPs has been tested for animals in simple ecosystems (e.g., a single food chain involving cabbage, caterpillar, and wasp: Chikaraishi et al. 2011). Few studies applying the SIAA method to complex food webs (e.g., where both aquatic- and terrestrial-derived resources potentially contribute to the diet of animals) have been reported (c.f., reconstruction of marine and terrestrial paleoenvironments: Naito et al. 2010). In stream food webs where aquatic and terrestrial resources are mixed, the proportion of resources derived from aquatic and terrestrial food chains can be used in the estimation of the TP of animals (e.g., macroinvertebrates and fishes), because aquatic and terrestrial primary producers have distinctive $\beta$ values in Eq. 1 . In this study we test the applicability of the SIAA method for analyzing stream food webs, with assumption of constant TEFs in $\delta^{15} \mathrm{~N}_{\text {Glu }}\left(8.0 \%\right.$ ) and $\delta^{15} \mathrm{~N}_{\text {Phe }}$ (0.4\%o) (Chikaraishi et al. 2009) for stream invertebrates and fishes. We build a two-source mixing model using the $\delta^{15} \mathrm{~N}_{\text {Glu }}$ and $\delta^{15} \mathrm{~N}_{\text {Phe }}$ values of periphyton, C3 litter, and animals to estimate both resource importance and trophic pathways in stream food webs.

\section{Materials and methods}

\section{Study sites and sample collection}

In November (winter) 2011 and May (summer) 2012, stream macroinvertebrates, fishes, and 
Ishikawa et al. Amino acid $\delta^{15} \mathrm{~N}$ of stream animals

their potential food sources (periphyton and terrestrial C3 litter) were collected from upper and lower sites of the Yasu River and the Ado River, central Japan (Table A1, Fig. A1, A2). The Yasu River is the largest watershed in the Lake Biwa basin: the upper site is pristine while the lower site is affected by urban development. The concentration and isotope value of nitrate increase in the downstream direction in the Yasu River (Ohte et al. 2010). The Ado River is the third largest watershed in the Lake Biwa basin. The natural landscape has been retained throughout its length, and the concentration and isotope value of nitrate do not greatly change along its course in the Ado River (Ohte et al. 2010). Several plants with C3 photosynthesis (Cupressaceae and Fagaceae) dominate the riparian vegetation at each of the study sites.

Aquatic invertebrates and fishes were collected at each site using a hand net. We also randomly collected several submerged river cobbles, which were rinsed gently with distilled water prior to collecting the periphyton from the cobble surface, using a brush and distilled water. The resulting slurry was placed into a 100-mL polypropylene bottle (3-5 replicates per site). The terrestrial C3 litter (hereafter, C3 litter) comprising C3 plants (mainly Fagaceae and Ericaceae), was collected from several leaf packs within the stream at each site: the exception was the lower site of the Yasu River in November, where no leaf packs were present: on this occasion, rather than C3 litter we collected particulate organic material (POM) using a surber net (mesh size $1000 \mu \mathrm{m}$ ) placed vertically in the current in the center of the channel. Neither C3 litter nor POM included C4 plants. All samples were held on ice in the dark until further processing in the laboratory. Gut contents of the invertebrates were not eliminated because some of them had been already dead during transportation. We identified and categorized invertebrates into functional feeding groups (FFGs: grazer; shredder; filter feeder; predator; and other invertebrates). Isotope measurements were based on single invertebrates where the body size was large enough for analysis (i.e., > $3.0 \mathrm{mg}$ dry weight per 
Ishikawa et al. Amino acid $\delta^{15} \mathrm{~N}$ of stream animals

individual), or were based on several individuals belonging to the same family, which were combined to form the sample for analysis. All samples were freeze-dried, and each was ground into a fine powder prior to analysis.

\section{Bulk stable carbon and nitrogen isotope measurements}

We measured the bulk stable carbon and nitrogen isotope ratios $\left(\delta^{13} \mathrm{C}_{\text {Bulk }}\right.$ and $\delta^{15} \mathrm{~N}_{\text {Bulk, }}$, respectively) of periphyton, C3 litter, invertebrates, and fishes. Each sample was packed into a tin capsule, and the $\delta^{13} \mathrm{C}_{\text {Bulk }}$ and $\delta^{15} \mathrm{~N}_{\text {Bulk }}$ (\%o) were measured using a Flash EA1112 elemental analyzer connected to a Delta XP isotope ratio mass spectrometer (Thermo Fisher Scientific, Waltham, MA, USA) with a Conflo III interface (Thermo Fisher Scientific). The $\delta^{13} \mathrm{C}$ and $\delta^{15} \mathrm{~N}$ values were reported relative to that of Vienna Pee Dee Belemnite (VPDB) and atmospheric $\mathrm{N}_{2}$ (Air), respectively. Data were corrected using internal standards (CERKU-01 DL-Alanine: $\delta^{13} \mathrm{C}_{\text {VPDB }}=-25.36 \%$ o, $\delta^{15} \mathrm{~N}_{\text {Air }}=-2.89 \%$; CERKU-02 L-Alanine: $\delta^{13} C_{V P D B}=-$ 19.04\%o, $\delta^{15} \mathrm{~N}_{\text {Air }}=+22.71 \%$; CERKU-03 Glycine: $\delta^{13} \mathrm{C}_{\mathrm{VPDB}}=-34.92 \%$ o, $\delta^{15} \mathrm{~N}_{\text {Air }}=+2.18 \%$ o) that were corrected to multiple international standards (Tayasu et al. 2011). The standard deviations of the $\delta^{13} \mathrm{C}_{\text {Bulk }}$ and $\delta^{15} \mathrm{~N}_{\text {Bulk }}$ measurements were within $0.10 \%$ and $0.14 \%$, respectively.

\section{Amino acid purification and stable nitrogen isotope measurement}

For compound-specific isotope analysis, amino acids in all samples were purified by $\mathrm{HCl}$ hydrolysis followed by $N$-pivaloyl/isopropyl (Pv/iPr) addition, according to the improved procedures of Chikaraishi et al. (2007). In brief, samples of animals ( $3 \mathrm{mg}$ ) and periphyton, POM, and C3 litter ( 20 mg) were hydrolyzed in $12 \mathrm{~mol} \mathrm{~L}^{-1} \mathrm{HCl}$ at $110{ }^{\circ} \mathrm{C}$ for $12 \mathrm{~h}$. The hydrolysates were filtrated through a pipette stuffed with quartz wool, washed with $n$-hexane/dichloromethane (3:2, v/v) to remove large particles and hydrophobic constituents 
Ishikawa et al. Amino acid $\delta^{15} \mathrm{~N}$ of stream animals

(e.g., lipids), respectively, and evaporated to dryness under a $\mathrm{N}_{2}$ stream. After derivatization with thionyl chloride/2-propanol (1:4, v/v) at $110{ }^{\circ} \mathrm{C}$ for $2 \mathrm{~h}$ and pivaloyl

chloride/dichloromethane $(1: 4, \mathrm{v} / \mathrm{v})$ at $110^{\circ} \mathrm{C}$ for $2 \mathrm{~h}$, and liquid-liquid extraction with $0.5 \mathrm{ml}$ of $n$-hexane/dichloromethane (3:2, v/v) and $0.2 \mathrm{ml}$ of distilled water, the Pv/iPr derivatives of amino acids were dissolved in dichloromethane.

We measured the stable nitrogen isotopic composition of amino acids following the modified method of Chikaraishi et al. (2010b). Briefly, the $\delta^{15} \mathrm{~N}$ values of the individual amino acids were determined by gas chromatography/combustion/isotope ratio mass spectrometry (GC/C/IRMS) using a Delta V plus isotope ratio mass spectrometer (Thermo Fisher Scientific) coupled to a gas chromatograph (GC7890A; Agilent Technologies, Santa Clara, CA, USA) via a modified GC-Isolink interface consisting of combustion and reduction furnaces. The amino acid derivatives were injected into the GC column using a Gerstel PTV injector in solvent vent mode. The PTV temperature program was as follows: $50{ }^{\circ} \mathrm{C}$ (initial temperature) for $0.25 \mathrm{~min}$, heating from $50{ }^{\circ} \mathrm{C}$ to $270{ }^{\circ} \mathrm{C}$ at the rate of $600{ }^{\circ} \mathrm{C} \mathrm{min}{ }^{-1}$, isothermal hold at $270{ }^{\circ} \mathrm{C}$ for $10 \mathrm{~min}$. The combustion was performed in a microvolume ceramic tube with $\mathrm{CuO}, \mathrm{NiO}$, and $\mathrm{Pt}$ wires at $1030{ }^{\circ} \mathrm{C}$, and the reduction was performed in a microvolume ceramic tube with reduced $\mathrm{Cu}$ wire at $650^{\circ} \mathrm{C}$. The $\mathrm{GC}$ was equipped with an Ultra-2 capillary column (50 m, 0.32 mm i.d., $0.52 \mu \mathrm{m}$ film thickness; Agilent Technologies). The GC oven temperature was programmed as follows: initial temperature $40{ }^{\circ} \mathrm{C}$ for $2.5 \mathrm{~min}$, increase at $15^{\circ} \mathrm{C} \min ^{-1}$ to $110^{\circ} \mathrm{C}$, increase at $3^{\circ} \mathrm{C} \mathrm{min}-1$ to $150{ }^{\circ} \mathrm{C}$, increase at $6{ }^{\circ} \mathrm{C} \mathrm{min}^{-1}$ to $220^{\circ} \mathrm{C}$, hold at the final temperature for $14 \mathrm{~min}$. The carrier gas (He) flow rate through the GC column was $1.4 \mathrm{ml} \mathrm{min}{ }^{-1}$. The $\mathrm{CO}_{2}$ generated in the combustion furnace was removed using a liquid nitrogen trap. Standard mixtures of at least 5 amino acids $\left(\delta^{15} \mathrm{~N}\right.$ ranging from 6.27 to $+22.71 \%$ o) were analyzed every $1-6$ samples to confirm the reproducibility of the isotope measurements. Analytical errors $(1 \sigma)$ of the standards were better than $0.7 \%$ with a 
Ishikawa et al. Amino acid $\delta^{15} \mathrm{~N}$ of stream animals

200

201

202

203

204

205

206

207

208

209

210

211

212

213

214

215

216

217

minimum sample quantity of $60 \mathrm{ng} \mathrm{N}$.

\section{Estimation of periphyton contribution and trophic position}

Two-isotope and two-source mixing models are widely used in various ecological studies including food web research (e.g., Fry 2006). Using $\delta^{15} \mathrm{~N}_{\text {Bulk }}$ and $\delta^{13} \mathrm{C}_{\text {Bulk values of periphyton }}$ (average of 3-5 replicates), C3 litter, and animals at each site, the local periphyton contributions to animals relative to C3 litter (f) were calculated using Eq. 2 (see Appendix for more details on algebraic procedures):

$f=\frac{\frac{\delta^{15} \mathrm{~N}_{\text {Bulk }}[\mathrm{A}]-\delta^{15} \mathrm{~N}_{\text {Bulk }}[\mathrm{L}]}{\Delta_{\mathrm{N}}}-\frac{\delta^{13} \mathrm{C}_{\mathrm{Bulk}}[\mathrm{A}]-\delta^{13} \mathrm{C}_{\mathrm{Bulk}}[\mathrm{L}]}{\Delta_{\mathrm{C}}}}{\frac{\delta^{15} \mathrm{~N}_{\mathrm{Bulk}}[\mathrm{P}]-\delta^{15} \mathrm{~N}_{\text {Bulk }}[\mathrm{L}]}{\Delta_{\mathrm{N}}}-\frac{\delta^{13} \mathrm{C}_{\mathrm{Bulk}}[\mathrm{P}]-\delta^{13} \mathrm{C}_{\mathrm{Bulk}}[\mathrm{L}]}{\Delta_{\mathrm{C}}}}$

where $0 \leq f \leq 1$ and $\delta^{15} \mathrm{~N}_{\text {Bulk }}[\mathrm{A}], \delta^{13} \mathrm{C}_{\text {Bulk }}[\mathrm{A}], \delta^{15} \mathrm{~N}_{\text {Bulk }}[\mathrm{L}], \delta^{13} \mathrm{C}_{\mathrm{Bulk}}[\mathrm{L}], \delta^{15} \mathrm{~N}_{\text {Bulk }}[\mathrm{P}]$, and $\delta^{13} \mathrm{C}_{\mathrm{Bulk}}[\mathrm{P}]$ are $\delta^{15} \mathrm{~N}_{\text {Bulk }}$ and $\delta^{13} \mathrm{C}_{\text {Bulk }}$ of animal [A], those of C3 litter [L], and those of periphyton [P] in each site, respectively. $\Delta_{\mathrm{N}}$ and $\Delta_{\mathrm{C}}$ are trophic enrichment factors for $\delta^{15} \mathrm{~N}_{\text {Bulk }}$ (3.4\%o) and $\delta^{13} C_{\text {Bulk }}(0.8 \%$ ), respectively (Vander Zanden and Rasmussen 2001). Using Eq. 2, the TPs of animals were estimated according to Eq. 3:

$\mathrm{TP}=\frac{\delta^{15} \mathrm{~N}_{\text {Bulk }}[\mathrm{A}]-\delta^{13} \mathrm{C}_{\text {Bulk }}[\mathrm{A}]-\left\{f\left(\delta^{15} \mathrm{~N}_{\text {Bulk }}[\mathrm{P}]-\delta^{13} \mathrm{C}_{\mathrm{Bulk}}[\mathrm{P}]\right)+(1-f)\left(\delta^{15} \mathrm{~N}_{\text {Bulk }}[\mathrm{L}]-\delta^{13} \mathrm{C}_{\mathrm{Bulk}}[\mathrm{L}]\right)\right\}}{\Delta_{\mathrm{N}}-\Delta_{\mathrm{C}}}+1$

litter, and animals at each site, the local periphyton contributions to animals relative to C3 
Ishikawa et al. Amino acid $\delta^{15} \mathrm{~N}$ of stream animals

224

litter $(g)$ were calculated in the same manner:

$g=\frac{\frac{\delta^{15} \mathrm{~N}_{\mathrm{Glu}}[\mathrm{A}]-\delta^{15} \mathrm{~N}_{\mathrm{Glu}}[\mathrm{L}]}{\Delta_{\mathrm{Glu}}}-\frac{\delta^{15} \mathrm{~N}_{\mathrm{Phe}}[\mathrm{A}]-\delta^{15} \mathrm{~N}_{\mathrm{Phe}}[\mathrm{L}]}{\Delta_{\mathrm{Phe}}}}{\frac{\delta^{15} \mathrm{~N}_{\mathrm{Glu}}[\mathrm{P}]-\delta^{15} \mathrm{~N}_{\mathrm{Glu}}[\mathrm{L}]}{\Delta_{\mathrm{Glu}}}-\frac{\delta^{15} \mathrm{~N}_{\mathrm{Phe}}[\mathrm{P}]-\delta^{15} \mathrm{~N}_{\mathrm{Phe}}[\mathrm{L}]}{\Delta \text { Phe }}}$

where $0 \leq g \leq 1$ and $\delta^{15} \mathrm{~N}_{\mathrm{Glu}}[\mathrm{A}], \delta^{15} \mathrm{~N}_{\mathrm{Phe}}[\mathrm{A}], \delta^{15} \mathrm{~N}_{\mathrm{Glu}}[\mathrm{L}], \delta^{15} \mathrm{~N}_{\mathrm{Phe}}[\mathrm{L}], \delta^{15} \mathrm{~N}_{\mathrm{Glu}}[\mathrm{P}]$, and $\delta^{15} \mathrm{~N}_{\mathrm{Phe}}[\mathrm{P}]$ are $\delta^{15} \mathrm{~N}_{\text {Glu }}$ and $\delta^{15} \mathrm{~N}_{\text {Phe }}$ of animal [A], those of C3 litter [L], and those of periphyton [P] in each site, respectively. $\Delta_{\text {Glu }}$ and $\Delta_{\text {Phe }}$ are trophic enrichment factors for $\delta^{15} \mathrm{~N}_{\text {Glu }}(8.0 \%$ ) and $\delta^{15} \mathrm{~N}_{\text {Phe }}$ (0.4\%o), respectively (Chikaraishi al. 2009). Using Eq. 4, the TPs of animals were estimated according to Eq. 5:

$\mathrm{TP}=\frac{\delta^{15} \mathrm{~N}_{\mathrm{Glu}}[\mathrm{A}]-\delta^{15} \mathrm{~N}_{\mathrm{Phe}}[\mathrm{A}]-\left\{g\left(\delta^{15} \mathrm{~N}_{\mathrm{Glu}}[\mathrm{P}]-\delta^{15} \mathrm{~N}_{\mathrm{Phe}}[\mathrm{P}]\right)+(1-g)\left(\delta^{15} \mathrm{~N}_{\mathrm{Glu}}[\mathrm{L}]-\delta^{15} \mathrm{~N}_{\mathrm{Phe}}[\mathrm{L}]\right)\right\}}{\Delta_{\mathrm{Glu}}-\Delta_{\mathrm{Phe}}}+1$

Animals for which the periphyton contributions were calculated to be $>100 \%$ or $<0 \%$ were removed from the analysis (7 of a total of 87 data points). Data on C3 litter were not available for the lower site of the Yasu River in November and consequently the TPs of animals at this site were not calculated (11 of a total of 87 data points). All statistical analyses and graphing were performed using R 2.14.2 software (R Development Core Team 2012), with the significance level set $\alpha=0.01$.

\section{Results}


Ishikawa et al. Amino acid $\delta^{15} \mathrm{~N}$ of stream animals

\section{Bulk stable carbon and nitrogen isotope ratios}

Analysis of variance showed that the $\delta^{15} \mathrm{~N}_{\text {Bulk }}$ values of periphyton were significantly different between the two sites (upper sites vs. lower sites; $p<0.001$ ), but were not different between the two seasons (November vs. May; $p=0.14$ ) or between the two rivers (Yasu vs. Ado; $p=$ 0.20). In both November and May the $\delta^{15} \mathrm{~N}_{\text {Bulk }}$ values of periphyton in the Yasu River were significantly lower at the upper site $(-2.4 \pm 0.76 \%$, mean \pm 1 standard deviation, $n=7)$ than the lower site ( $+5.9 \pm 1.95 \%$ o, $n=8$ ) (Tukey’s HSD, $p<0.001$ in both seasons). In contrast,

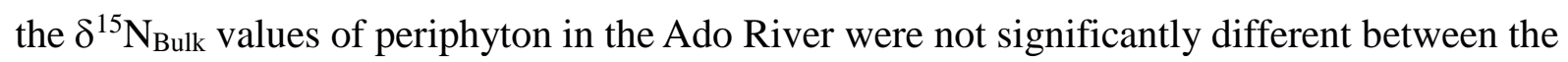
upper site $(+0.5 \pm 0.68 \%$ o, $n=9)$ and the lower site $(+1.7 \pm 0.45 \%$, $n=8)$ (Tukey’s HSD, $p=$ 0.35 in November and $p=0.10$ in May; Fig. 1,2$)$. The $\delta^{13} C_{\text {Bulk values of periphyton showed }}$ large intra-site variations (5-10\%) in all sites, while those of the C3 litter remained relatively constant among sites (ca. -30\%) (Fig. 1, 2). For animals, the $\delta^{13} C_{\text {Bulk values fell mostly }}$

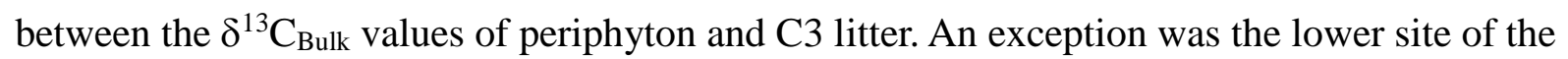
Ado River in November, where the $\delta^{13} \mathrm{C}_{\text {Bulk }}$ values of some animals were higher than those of

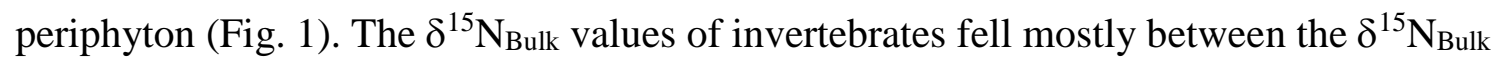
values of primary producers (i.e., periphyton and C3 litter) and fishes. An exception was the

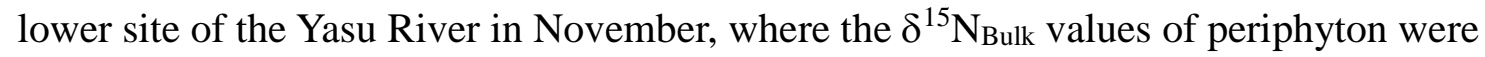
higher than those of invertebrates (Fig. 1). Overall, the amount of animals’ $\delta^{15} \mathrm{~N}_{\text {Bulk }}$ and $\delta^{13} \mathrm{C}_{\mathrm{Bulk}}$ data that could be used for calculation of two-source mixing model was larger in May (31 of a total of 37 data points) than in November (20 of a total of 36 data points).

\section{Primary producers}

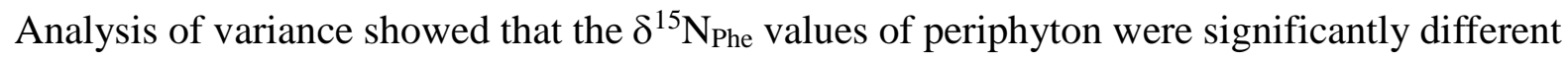
between the two sites $(p<0.001)$, but were not different between the two seasons $(p=0.10)$ or between the two rivers $(p=0.04)$. In both November and May, the $\delta^{15} \mathrm{~N}_{\text {Phe values of }}$ 
Ishikawa et al. Amino acid $\delta^{15} \mathrm{~N}$ of stream animals

270

271

periphyton in the Yasu River were significantly lower at the upper site $(-4.2 \pm 1.80 \%, n=6)$ than the lower site ( $+4.8 \pm 2.52 \%$ o, $n=8$ ) (Tukey’s HSD, $p<0.001$ in both seasons). In

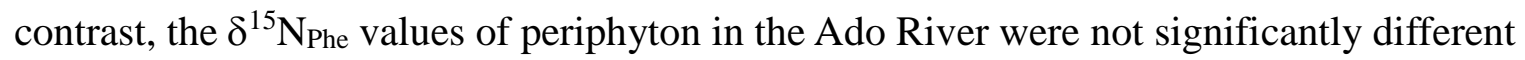
between the upper site $(-1.4 \pm 1.92 \%, n=8)$ and the lower site $(-0.9 \pm 1.05 \%, n=8)$ (Tukey’s HSD, $p>0.99$ in both seasons; Fig. 3, 4). The differences between the $\delta^{15} \mathrm{~N}_{\mathrm{Glu}}$ and

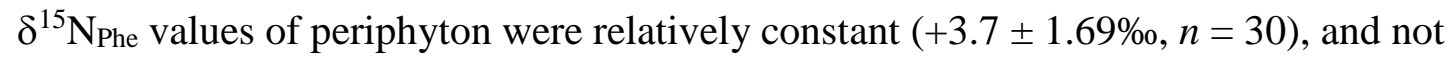
significantly different from those reported for aquatic primary producers (Chikaraishi et al. 2009: $+3.4 \pm 0.9 \%$ o, $n=25$ ) (Wilcoxon test: $W=327, p=0.42$ ). However, the differences

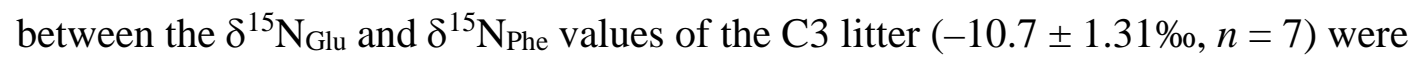
significantly different from those reported for terrestrial C3 plants (Chikaraishi et al. 2010a: $8.4 \pm 1.6 \%, n=17$ ) (Wilcoxon test: $W=104, p=0.005$ ). The difference between $\delta^{15} \mathrm{~N}_{\text {Glu }}$ and

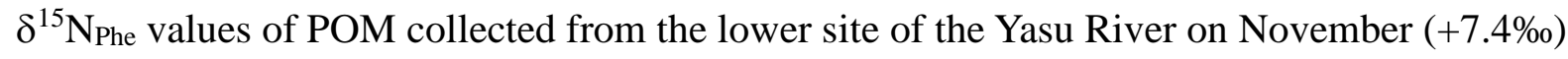
was higher than those of aquatic primary producers (+3.4\%) and terrestrial C3 plants (-8.4\%o) (Fig. 3c), indicating that POM included not only primary producers, but also living and/or dead heterotrophs.

\section{Primary consumers}

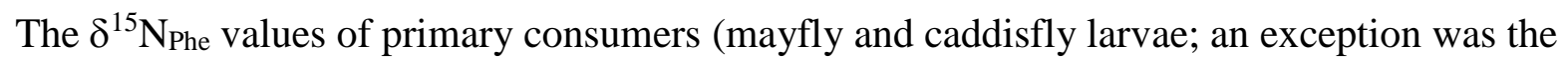
larvae of the leaf shredding caddisfly Lepidostoma japonicum) in the Yasu River were much lower at the upper site $(-4.5 \pm 2.57 \%$ o, $n=5)$ than the lower site $(+6.2 \pm 2.35 \%$ o, $n=7)$, while

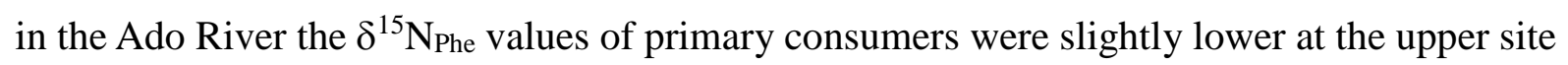
$(-0.2 \pm 1.64 \%$ o, $n=7)$ than the lower site $(+1.1 \pm 0.59 \%$, $n=7)$. For grazing mayflies (larvae of Heptageniidae spp. and Baetis spp.) the $\delta^{15} \mathrm{~N}_{\mathrm{Glu}}$ values were approximately $8 \%$ o higher than

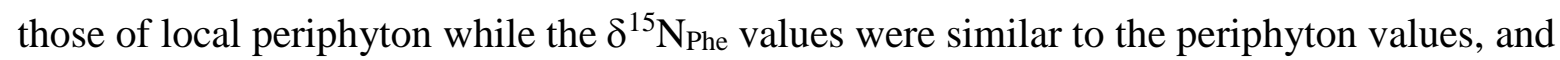
thus they were located near the line of aquatic TL $=2$ (Fig. 3, 4). The two-source mixing 
Ishikawa et al. Amino acid $\delta^{15} \mathrm{~N}$ of stream animals

295

296

model showed that the reliance of mayflies on periphyton was $90 \pm 6.5 \%$ ( $n=9$; Fig. 5a) with the TP of $2.1 \pm 0.08$ ( $n=9$; Fig. 5b). The $\delta^{15} \mathrm{~N}_{\text {Glu }}$ and $\delta^{15} \mathrm{~N}_{\text {Phe }}$ values of filter feeding caddisflies (larvae of Hydropsychidae spp. and Stenopsyche marmorata) showed large variations among sites and seasons, but their reliance on periphyton $(87 \pm 3.3 \%, n=8)$ and TP (2.2 $\pm 0.14, n=8$ ) were less variable than other animals (Fig. 5). The $\delta^{15} \mathrm{~N}_{\text {Phe }}$ values of larvae of the leaf shredding caddisfly L. japonicum were 10-15\%o higher than those of local periphyton, and were similar to that of C3 litter. The periphyton contribution to shredders was thus estimated to be $24 \pm 16.9 \%$ ( $n=5$, Fig. 5 a) with the TP of $2.0 \pm 0.27$ ( $n=5$, Fig. 5b).

\section{Secondary consumers and fishes}

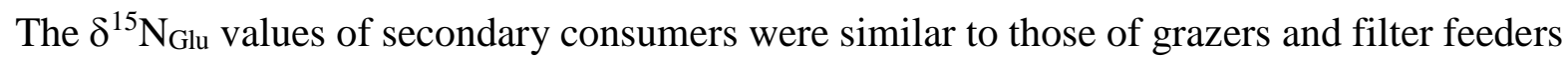
(Fig. 5). As with the primary consumers, the $\delta^{15} \mathrm{~N}_{\text {Phe values of secondary consumers (i.e., }}$ predatory larvae: the dragonfly Gomphidae spp.; the stoneflies Kamimuria tibialis, Chloroperlidae spp., Paragnetina tinctipennis, Oyamia lugubris, Niponiella limbatella; and the dobsonfly Protohermes grandis) in the Yasu River were much lower at the upper site $(-0.9$ $\pm 1.09 \%$ o, $n=5)$ than the lower site $(+6.3 \pm 1.61 \%$ o, $n=7)$, while in the Ado River there was only a small difference between the upper site $(+1.3 \pm 0.94 \%, n=15)$ and the lower site $(+1.5$ $\pm 1.39 \%$, $n=7)$. Dragonfly, stoneflies, and dobsonfly were $85 \pm 8.5 \%(n=4), 81 \pm 9.0 \%(n=$ 18), and $82 \pm 10.0 \%(n=5)$ reliant on periphyton, respectively (Fig. 5a). The TPs of predators (dragonfly: $2.3 \pm 0.10$; stoneflies: $2.5 \pm 0.25$; dobsonfly: $2.3 \pm 0.18$ ) were higher than those of primary consumers, but were $<3$ (Fig. 5b). Larvae of the crane fly (Tipulidae spp., FFG not specified) were $70 \pm 9.0 \%$ ( $n=4$; Fig. 5a) reliant on periphyton with the TP of $2.5 \pm 0.23(n=$ 4; Fig. 5b). Fishes, including demersal goby (Rhinogobius spp.) and other fishes (trout, chub, and minnow) were $77 \pm 8.0 \%(n=10)$ and $78 \pm 10.9 \%(n=6)$ reliant on periphyton, respectively (Fig. 5a). The TPs in our dataset were highest for fishes (Fig. 5b), including for 
Ishikawa et al. Amino acid $\delta^{15} \mathrm{~N}$ of stream animals goby $(3.1 \pm 0.28, n=10)$ and the other fishes $(2.8 \pm 0.25, n=6)$.

The amount of animals' $\delta^{15} \mathrm{~N}_{\mathrm{Glu}}$ and $\delta^{15} \mathrm{~N}_{\text {Phe }}$ data that could be used for calculation of two-source mixing model was similar between November (36 of a total of 39 data points) and May (33 of a total of 37 data points). Analysis of variance showed that the periphyton contributions (relative to the C3 litter) to animals were significantly different between the two seasons and the two rivers, and among animal groups, but were not significantly different between the two sites (Table A2). Periphyton contribution percentage in the Yasu River and May were significantly lower than in the Ado River and November (Tukey’s HSD, $p<0.001$ ). The TPs of animals were significantly different between seasons, sites (marginally), and among animal groups, but were not significantly different between rivers (Table A3). The TPs of animals in November were significantly lower than those in May (Tukey's HSD, $p<0.01$ ).

\section{Comparisons between bulk and SIAA methods}

Based on Eq. 2-5, TPs estimated from $\delta^{15} \mathrm{~N}_{\text {Bulk }}$ and $\delta^{13} \mathrm{C}_{\text {Bulk }}$ values and from $\delta^{15} \mathrm{~N}_{\text {Glu }}$ and

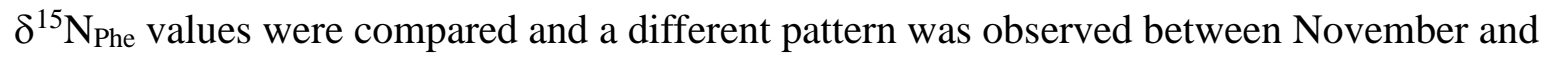
May (Fig. 6). The amount of data for November was small because the $\delta^{15} \mathrm{~N}_{\text {Bulk }}$ and $\delta^{13} \mathrm{C}_{\text {Bulk }}$ values of periphyton were too variable to construct a two-source mixing model for estimating the relative contributions of periphyton and C3 litter to animals (Fig. 1): approximately 50\% of the data points for animals were removed from the analysis because the estimated periphyton contributions exceeded $100 \%$. Furthermore, the bulk estimated TPs for November were different from the SIAA estimated TPs: the SIAA estimated TPs ranged from 2 to 3, while the bulk estimated TPs varied widely from 1 to 4 (Fig. 6a). On the other hand, as the $\delta^{13} \mathrm{C}_{\mathrm{Bulk}}$ values of animals for May were between those of periphyton and C3 litter, and the

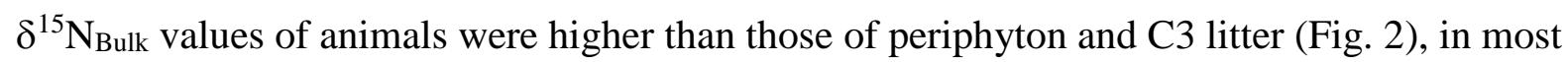
cases the periphyton contribution to animals, and their TPs, were estimated. The TPs for May, 
Ishikawa et al. Amino acid $\delta^{15} \mathrm{~N}$ of stream animals

estimated using the bulk and SIAA methods, were more alike than those for November, although for several primary consumers (grazers and shredders) the bulk method provided TP estimates $<2$ (Fig. 6b).

\section{Discussion}

The stable nitrogen isotopic composition of amino acids (SIAA) is useful for understanding the structure of stream food webs: this conclusion was induced by comparing the resource reliance and trophic positions determined using bulk and SIAA methods for a range of variable stream conditions (upper vs. lower parts of the streams; pristine vs. urbanized landscapes; and summer vs. winter). One important assumption of the linear mixing model

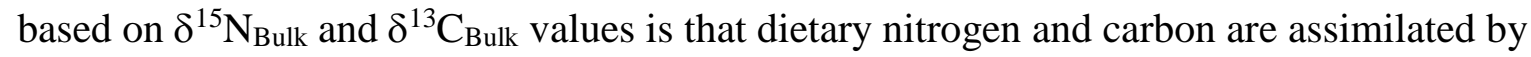
animals in the same proportions (Phillips and Koch 2002), although the C:N ratios of animals and those of their diets are not necessarily identical in natural food webs (Post 2002). The SIAA method does not rely on this assumption because the biplot for $\delta^{15} \mathrm{~N}_{\text {Glu }}$ and $\delta^{15} \mathrm{~N}_{\text {Phe }}$ defines the food web structure based on the metabolic pathway of amino groups.

Our seasonal data showed two contrasting results for the bulk methods. The $\delta^{15} \mathrm{~N}_{\text {Bulk }}$ and $\delta^{13} \mathrm{C}_{\mathrm{Bulk}}$ values for May were able to estimate relative contributions of periphyton and C3 litter to animals, and the bulk estimated TPs were well correlated with the SIAA estimated TPs (Fig. 6b), suggesting that both methods are applicable to stream food web analysis. However, the bulk method was not applicable to analyzing stream food webs in November,

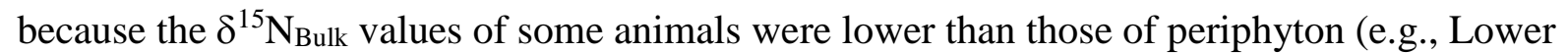
Yasu; Fig. 1), and because the $\delta^{13} \mathrm{C}_{\mathrm{Bulk}}$ values of some animals were not between those of periphyton and C3 litter (e.g., Lower Ado; Fig. 1). As noted in many reports, variations in enrichment of $\delta^{15} \mathrm{~N}_{\text {Bulk }}$ among taxa and variations in the $\delta^{13} \mathrm{C}_{\text {Bulk }}$ values of periphyton may 
Ishikawa et al. Amino acid $\delta^{15} \mathrm{~N}$ of stream animals

have caused problems in the analysis of stream food webs (McCutchan et al. 2003; Dekar et al. 2009; Ishikawa et al. 2012; Bunn et al. 2013). In November, the bulk estimated TPs were not consistent with the SIAA estimated TPs, and the former provided contradictory results in some animals (e.g., the TPs of some invertebrates were $<2$, Fig. 6a). In contrast, our results

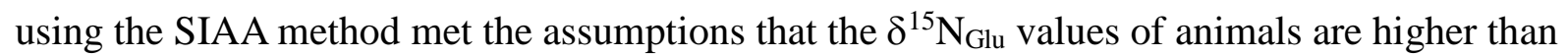

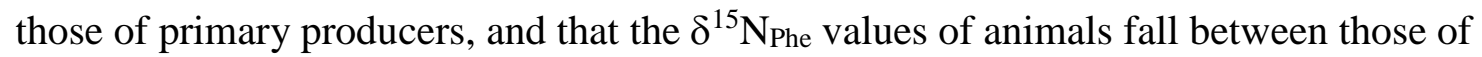
periphyton and C3 litter (Fig. 3, 4). The results indicate that both periphyton and C3 litter support stream food webs, and that animals at higher trophic positions integrate aquatic and terrestrial food chains.

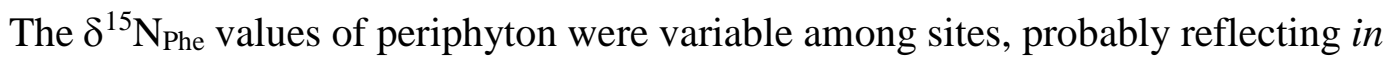
situ nutrient conditions (Pastor et al. 2013). In the Yasu River the $\delta^{15} \mathrm{~N}_{\text {Bulk }}$ and $\delta^{15} \mathrm{~N}_{\text {Phe values }}$ of periphyton were higher at the lower site than the upper site, but this was not the case for the Ado River. The result is consistent with the pattern of elevation of $\delta^{15} \mathrm{~N}-\mathrm{NO}_{3}$ along the Yasu River reflecting anthropogenic nitrogen loading in the urbanized watershed (Ohte et al. 2010).

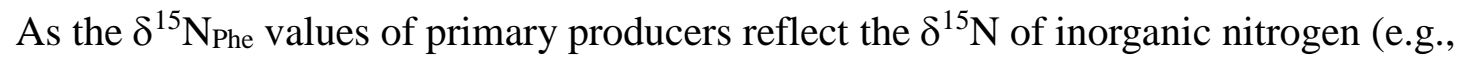
$\left.\delta^{15} \mathrm{~N}-\mathrm{NO}_{3}\right)\left(\right.$ Chikaraishi et al. 2009), the intra-site variation in $\delta^{15} \mathrm{~N}_{\text {Phe values of periphyton }}$ suggests that either $\delta^{15} \mathrm{~N}$ of inorganic nitrogen or fractionation between inorganic nitrogen and algae vary within a site. On the other hand, the $\delta^{15} \mathrm{~N}_{\text {Phe values of C3 litter were much }}$ higher than those of periphyton, and corresponded to or were below the terrestrial C3 baseline (TL = 1), expected on the basis of the results of Chikaraishi et al. (2010a; 2011). Terrestrial C3 plants synthesize lignin from phenylalanine through the phenylpropanoid pathway, but aquatic autotrophs do not (Bender 2012). Kinetic isotope fractionation from phenylalanine to

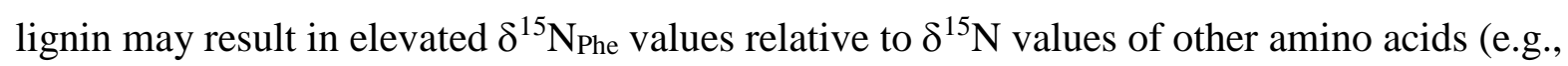
glutamic acid) in terrestrial C3 plants, and consequently relative to $\delta^{15} \mathrm{~N}_{\text {Phe values of aquatic }}$ autotrophs. Our results suggest that both aquatic and terrestrial primary producers have large 
Ishikawa et al. Amino acid $\delta^{15} \mathrm{~N}$ of stream animals

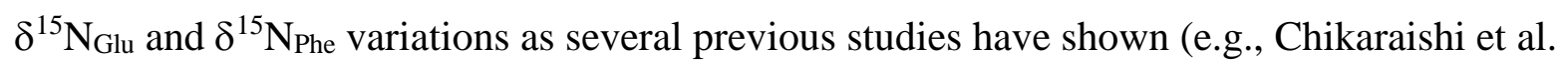
2009, 2011; Naito et al. 2013). Further studies will be necessary to elucidate what controls the large variations in the $\delta^{15} \mathrm{~N}_{\text {Glu }}$ and $\delta^{15} \mathrm{~N}_{\text {Phe values of primary producers in different }}$ environments.

The $\delta^{15} \mathrm{~N}_{\text {Glu }}$ values of grazers were approximately 8.0\%o higher than those of periphyton while the $\delta^{15} \mathrm{~N}_{\text {Phe }}$ values of both were similar, suggesting that grazing animals occupy the position of TL $=2$ in the aquatic food chain. On the other hand, the $\delta^{15} \mathrm{~N}_{\text {Phe values }}$ of shredders were slightly lower than those of C3 litter, suggesting that leaf shredding animals are partly subsidized by ${ }^{15} \mathrm{~N}_{\text {Phe-depleted aquatic resources. The two-source mixing model }}$ indicated that the periphyton contribution to predators was less than that to grazers, suggesting that predators rely on both aquatic and terrestrial resources. It also indicated that the TPs of predators were higher than those of grazers and shredders, but were $<3$, suggesting that the larvae of dragonfly, stonefly, and dobsonfly are not completely carnivores, but are partly omnivores. This result is consistent with previous gut content analysis showing that the larvae of two stoneflies (O. lugubris and K. tibialis) feed on both animals and algae (Miyasaka and Genkai-Kato 2009). In contrast, as the larvae of dragonfly and dobsonfly have highly specialized mouthparts for eating animal prey, and their guts include animals exclusively (Hayashi 1988; Takemon 2005), our TP estimates of dragonfly and dobsonfly larvae were lower than those predicted based on diet. In most cases the TPs of fishes were $>2$ but $<3$, suggesting that their diet includes autotrophs and heterotrophs derived from both aquatic and terrestrial food webs, and that they assimilate both animal- and plant-derived proteins.

In this study we assumed constant TEFs in $\delta^{15} \mathrm{~N}_{\text {Glu }}\left(\Delta_{\text {Glu }}=8.0 \%\right.$ ) and $\delta^{15} \mathrm{~N}_{\text {Phe }}\left(\Delta_{\text {Phe }}\right.$ $=0.4 \%$ ) for stream invertebrates and fishes, based on the metabolic theory of amino acids and several empirical observations (Chikaraishi et al. 2009; 2011; Steffan et al. 2013). The results 
Ishikawa et al. Amino acid $\delta^{15} \mathrm{~N}$ of stream animals

420

421

422

suggested that this assumption is reasonable for primary consumers (i.e., grazers and shredders), while it should be examined for secondary and higher consumers (e.g., the larvae of dragonfly and dobsonfly) in further studies. Indeed, the value of $\Delta_{\text {Glu }}-\Delta_{\text {Phe }}$ is reported as lower than 7.6\%o between some animals and their potential food sources (e.g., penguin:

3.4-3.8\%o, Lorrain et al. 2009; stingray and shark: $5.0 \pm 0.6 \%$, Dale et al. 2011). In addition, a feeding experiment indicated that the value of $\delta^{15} \mathrm{~N}_{\mathrm{Glu}}-\delta^{15} \mathrm{~N}_{\text {Phe }}$ in harbor seal is only 4.3\%o higher than the value of their exclusive diet (wild herring) (Germain et al. 2013).

The seasonal differences in periphyton contributions to animals suggest that high in-stream production in summer and/or large inputs of terrestrial resources in winter are reflected in the biomass of animals (Nakano and Murakami 2001). The TPs of animals were also slightly different between seasons, probably because the predator species analyzed were different between November and May: for example, the dominant stoneflies were K. tibialis in November $(\mathrm{TP}=2.3 \pm 0.19 ; \mathrm{N}=8)$, but were $N$. limbatella in May $(\mathrm{TP}=2.6 \pm 0.30 ; \mathrm{N}=6)$. We did not expect that the periphyton contributions would be lower in the Yasu River than in the Ado River, because the watershed of the former is more urbanized and has a higher dissolved nitrate concentration (Ohte et al. 2010), which would increase in-stream primary production. In addition, we did not find a significant difference in the periphyton contributions between upper and lower sites, suggesting that nitrogen transfer pathway in food webs does not greatly change along a river continuum.

Most ecosystems are open, and the movement of materials and energy among ecosystems plays an important role in several ecological processes (e.g., the addition of extra resources make food webs more complex: Polis et al. 1997; Nakano and Murakami 2001). Although the number of studies using the SIAA method for estimating the TPs of animals has recently increased (e.g., McClelland and Montoya 2002; Popp et al. 2007; Miller et al. 2013), these studies have been limited to simple food chain systems (to our knowledge exceptions 
Ishikawa et al. Amino acid $\delta^{15} \mathrm{~N}$ of stream animals

445

446

447

are a few archaeological studies; Naito et al. 2010; 2013; Styring et al. 2010) because aquatic and terrestrial primary producers have distinctive $\delta^{15} \mathrm{~N}$ differences between source amino acids (e.g., phenylalanine) and trophic amino acids (e.g., glutamic acid) (Chikaraishi et al. 2009; 2010a). We overcome this limitation by applying a two-source mixing model to stream food webs involving mixed aquatic and terrestrial resources. Our data suggest novel applications of the SIAA method in addition to estimating the TPs of animals, assessing the relative contributions of aquatic and terrestrial resources to animals (Fig. 7): this structure is central to understanding how aquatic and terrestrial food chains are incorporated into stream ecosystems. Furthermore, amino acids are fundamental to the transfer of nitrogen within and among ecosystems (Bender 2012). Based on these advantages, we conclude that a mixing model using the SIAA method can provide useful information for the analysis of complex food webs and nitrogen cycling in natural ecosystems. 
Ishikawa et al. Amino acid $\delta^{15} \mathrm{~N}$ of stream animals

458

459

460

461

462

463

464

465

466

467

468

\section{Acknowledgments}

We thank M. Itoh, K. Osaka, Y. Kohmatsu, H. Nakagawa, T. Egusa, S. Ishikawa, W. Hidaka, Y. Tamiya, and Y. Takaoka for their assistance in fieldwork. Y. Chikaraishi, N. Ohkouchi, R. O. Hall, and two anonymous reviewers provided valuable comments on an early draft of this manuscript. This research was supported by the Environment Research and Technology Development Fund (D-1102) of the Ministry of the Environment, Japan. Partial support was also provided by the River Fund (24-1215-022) in charge of River Foundation and Grant-in-Aid for Scientific Research (B) (No.25291101). N.F.I. was supported by the Research Fellowship for Young Scientists (25-1021) of the Japan Society for the Promotion of Science. 
Ishikawa et al. Amino acid $\delta^{15} \mathrm{~N}$ of stream animals

\section{References}

Baxter CV, Fausch KD, Saunders WC (2005) Tangled webs: reciprocal flows of invertebrate prey link streams and riparian zones. Freshw Biol 50:201-220

Bender DA (2012) Amino acid metabolism. 3rd edn. Wiley-Blackwell, Oxford

Bunn SE, Leigh C, Jardine TD (2013) Diet-tissue fractionation of $\delta^{15} \mathrm{~N}$ by consumers from streams and rivers. Limnol Oceanogr 58:765-773

Carpenter SR, Cole JJ, Pace ML, Van de Bogert M, Bade DL, Bastviken D, Gille CM, Hodgson JR, Kitchell JF, Kritzberg ES (2005) Ecosystem subsidies: Terrestrial support of aquatic food webs from C-13 addition to contrasting lakes. Ecology 86:2737-2750

Chikaraishi Y, Kashiyama Y, Ogawa NO, Kitazato H, Ohkouchi N (2007) Biosynthetic and metabolic controls of nitrogen isotopic composition of amino acids in marine macroalgae and gastropods: implications for aquatic food web studies. Mar Ecol Prog Ser 342:85-90

Chikaraishi Y, Ogawa NO, Kashiyama Y, Takano Y, Suga H, Tomitani A, Miyashita H, Kitazato H, Ohkouchi N (2009) Determination of aquatic food-web structure based on compound-specific nitrogen isotopic composition of amino acids. Limnol Oceanogr Meth 7:740-750

Chikaraishi Y, Ogawa NO, Ohkouchi N (2010a) Further evaluation of the trophic level estimation based on nitrogen isotopic composition of amino acids. In: Ohokouchi N, Tayasu I, Koba K (eds) Earth, life, and isotopes. Kyoto University Press, Kyoto, pp $37-51$

Chikaraishi Y, Takano Y, Ogawa NO, Ohkouchi N (2010b) Instrumental optimization of compound-specific isotope analysis of amino acids by gas chromatography/combustion/isotope ratio mass spectrometry. In: Ohokouchi N, Tayasu 
Ishikawa et al. Amino acid $\delta^{15} \mathrm{~N}$ of stream animals

I, Koba K (eds) Earth, life, and isotopes. Kyoto University Press, Kyoto, pp 367-386

Chikaraishi Y, Ogawa NO, Doi H, Ohkouchi N (2011) ${ }^{15} \mathrm{~N} /{ }^{14} \mathrm{~N}$ ratios of amino acids as a tool for studying terrestrial food webs: a case study of terrestrial insects (bees, wasps, and hornets). Ecol Res 26:835-844

Cummins KW (1973) Trophic relations of aquatic insects. Annu Rev Entomol 18:183-206

Dale JJ, Wallsgrove NJ, Popp BN, Holland KN (2011) Nursery habitat use and foraging ecology of the brown stingray Dasyatis lata determined from stomach contents, bulk and amino acid stable isotopes. Mar Ecol Prog Ser 433:221-236

Deines P (1980) The isotopic composition of reduced organic carbon. In: Fritz P, Fontes JC (eds) Handbook of environmental isotope geochemistry. The terrestrial environment, A, vol. 1. Elsevier, Amsterdam, pp 329-406

Dekar MP, Magoulick DD, Huxel GR (2009) Shifts in the trophic base of intermittent stream food webs. Hydrobiologia 635:263-277

Fisher SG, Likens GE (1973) Energy flow in Bear Brook, New Hampshire: an integrative approach to stream ecosystem. Ecol Monogr 43:421-439

Fry B (1991) Stable isotope diagrams of freshwater food webs. Ecology 72:2293-2297

Fry B (2006) Stable isotope ecology. Springer New York, USA

Germain LR, Koch PL, Harvey J, McCarthy MD (2013) Nitrogen isotope fractionation in amino acids from harbor seals: implications for compound-specific trophic position calculations. Mar Ecol Prog Ser 482:265-277

Hayashi F (1988) Prey selection by the dobsonfly larva, Protohermes grandis (Megaloptera: Corydalidae). Freshw Biol 20:19-29

Hynes HBN (1970) The ecology of stream insects. Annu Rev Entomol 15:25-42

Ishikawa NF, Doi H, Finlay JC (2012) Global meta-analysis for controlling factors on carbon stable isotope ratios of lotic periphyton. Oecologia 170:541-549 
Ishikawa et al. Amino acid $\delta^{15} \mathrm{~N}$ of stream animals

Lindeman RL (1942) The trophic-dynamic aspect of ecology. Ecology 23:399-418

Lorrain A, Graham B, Ménard F, Popp B, Bouillon S, van Breugel P, Cherel Y (2009) Nitrogen and carbon isotope values of individual amino acids: a tool to study foraging ecology of penguins in the Southern Ocean. Mar Ecol Prog Ser 391:293-306

Marczak LB, Thompson RM, Richardson JS (2007) Meta-analysis: trophic level, habitat, and productivity shape the food web effects of resource subsidies. Ecology 88:140-148

McClelland JW, Montoya JP (2002) Trophic relationships and the nitrogen isotopic composition of amino acids in plankton. Ecology 83:2173-2180

McCutchan JM Jr, Lewis WM Jr, McGrath CC (2003) Variation in trophic shift for stable isotope ratios of carbon, nitrogen, and sulfur. Oikos 102:378-390

Miller MJ, Chikaraishi Y, Ogawa NO, Yamada Y, Tsukamoto K Ohkouchi N (2013) A low trophic position of Japanese eel larvae indicates feeding on marine snow. Biol Lett 9: 20120826

Minagawa M, Wada E (1984) Stepwise enrichment of ${ }^{15} \mathrm{~N}$ along food chains: further evidences and the relation between $\delta^{15} \mathrm{~N}$ and animal age. Geochim Cosmochim Acta 48:1135-1140

Miyasaka H, Genkai-Kato M (2009) Shift between carnivory and omnivory in stream stonefly predators. Ecol Res 24:11-19

Naito YI, Honch NV, Chikaraishi Y, Ohkouchi N, Yoneda M (2010) Quantitative evaluation of marine protein contribution in ancient diets based on nitrogen isotope ratios of individual amino acids in bone collagen: an investigation at the Kitakogane Jomon site. Am J Phys Anthropol 143:31-40

Naito YI, Chikaraishi Y, Ohkouchi N, Drucker DG, Bocherens H (2013) Nitrogen isotopic composition of collagen amino acids as an indicator of aquatic resource consumption: insights from Mesolithic and Epipalaeolithic archaeological sites in France. World 
Ishikawa et al. Amino acid $\delta^{15} \mathrm{~N}$ of stream animals

544

545

546

547

548

549

550

551

552

553

554

555

556

557

558

559

560

561

562

563

564

565

566

567

568

Archaeol 45:338-359

Nakano S, Murakami M (2001) Reciprocal subsidies: dynamic interdependence between terrestrial and aquatic food webs. Proc Natl Acad Sci USA 98:166-170

Ohte N, Tayasu I, Kohzu A, Yoshimizu C, Osaka K, Makabe A, Koba K, Yoshida N, Nagata T (2010) Spatial distribution of nitrate sources of rivers in the Lake Biwa watershed, Japan: controlling factors revealed by nitrogen and oxygen isotope values. Water Resour Res 46:W07505

Pastor A, Peipoch M, Cañas L, Chappuis E, Ribot M, Gacia E, Riera JL, Marti E, Sabater F (2013) Nitrogen stable isotopes in primary uptake compartments across streams differing in nutrient availability. Environ Sci Technol 47:10155-10162

Phillips DL, Koch PL (2002) Incorporating concentration dependence in stable isotope mixing models. Oecologia 130:114-125

Polis GA, Anderson WB, Holt RD (1997) Toward an integration of landscape and food web ecology: the dynamics of spatially subsidized food webs. Ann Rev Ecol Evol Syst 28:289-316

Popp BN, Graham BS, Olson RJ, Hannides CCS, Lott MJ, López-Ibarra G, Galván-Magaña F, Fry B (2007) Insight into the trophic ecology of yellowfin tuna, Thunnus albacares, from compound-specific nitrogen isotope analysis of proteinaceous amino acids. In T. E. Dawson and R. T. W. Siegwolf (eds) Stable isotopes as indicators of ecological change. Elsevier, pp 173-190

Post DM (2002) Using stable isotopes to estimate trophic position: models, methods, and assumptions. Ecology 83:703-718

Post DM, Pace ML, Hairston NG (2000) Ecosystem size determines food-chain length in lakes. Nature 405:1047-1049

R Development Core Team (2012) R: A language and environment for statistical computing. 
Ishikawa et al. Amino acid $\delta^{15} \mathrm{~N}$ of stream animals

R Foundation for Statistical Computing, Vienna, Austria. ISBN 3-900051-07-0, URL http://www.R-project.org.

Styring AK, Sealy JC, Evershed RP (2010) Resolving the bulk $\delta^{15} \mathrm{~N}$ values of ancient human and animal bone collagen via compound-specific nitrogen isotope analysis of constituent amino acids. Geochim Cosmochim Acta 74:241-251

Takemon Y (2005) Life-type concept and functional feeding groups of benthos communities as indicators of lotic ecosystem conditions. Japan J Ecol 55:189-197 [In Japanese]

Tayasu I, Hirasawa R, Ogawa NO, Ohkouchi N, Yamada K (2011) New organic reference materials for carbon and nitrogen stable isotope ratio measurements provided by Center for Ecological Research, Kyoto University and Institute of Biogeosciences, Japan Agency for Marine-Earth Science and Technology. Limnology 12:261-266

Thompson RM, Hemberg M, Starzomski BM, Shurin JB (2007) Trophic levels and trophic tangles: the prevalence of omnivory in real food webs. Ecology 88:612-617

Vander Zanden MJ, Rasmussen JB (2001) Variation in $\delta^{15} \mathrm{~N}$ and $\delta^{13} \mathrm{C}$ trophic fractionation: Implications for aquatic food web studies. Limnol Oceanogr 46:2061-2066

Vannote RL, Minshall GW, Cummins KW, Sedell JR, Cushing CE (1980) The river continuum concept. Can J Fish Aquat Sci 37:130-137

Winemiller KO (1990) Spatial and temporal variation in tropical fish trophic networks. Ecol Monogr 60:331-367 
2

\section{3}

4

5

6

\section{Stable nitrogen isotopic composition of amino acids reveals}

\section{food web structure in stream ecosystems}

Naoto F. Ishikawa ${ }^{1,4^{*}}$, Yoshikazu Kato ${ }^{1}$, Hiroyuki Togashi ${ }^{2,5}$, Mayumi Yoshimura ${ }^{3}$, Chikage

Yoshimizu $^{1}$, Noboru Okuda ${ }^{1}$, Ichiro Tayasu ${ }^{1}$

${ }^{1}$ Center for Ecological Research, Kyoto University, 2-509-3 Hirano, Otsu, Shiga 520-2113, Japan

${ }^{2}$ Field Science Education and Research Center, Kyoto University, Oiwake-cho, Kitashirakawa, Sakyo, Kyoto 606-8502, Japan

${ }^{3}$ Kansai Research Center, Forestry and Forest Products Research Institute, 68 Nagaikyutaroh, Momoyama, Fushimi, Kyoto, 612-0855, Japan

${ }^{4}$ Present address: Japan Agency for Marine-Earth Science and Technology, 2-15

Natsushima-cho, Yokosuka, Kanagawa 237-0061, Japan

${ }^{5}$ Present address: Tohoku National Fisheries Research Institute, Fisheries Research Agency, 3-27-5, Shinhama-cho, Shiogama, Miyagi 985-0001, Japan

${ }^{*}$ Corresponding author.

E-mail: ishikawan@jamstec.go.jp

Running head: Amino acid $\delta^{15} \mathrm{~N}$ of stream animals 


\section{Figure legends}

\section{Fig. 1.}

Biplot for the bulk stable carbon and nitrogen isotope ratios $\left(\delta^{13} \mathrm{C}_{\text {Bulk }}\right.$ and $\delta^{15} \mathrm{~N}_{\text {Bulk, }}$ respectively) of animals and their potential food sources collected in November 2011. Filled diamonds and squares are periphyton and terrestrial C3 litter, respectively. A cross surrounded by a square in Lower Yasu indicates particulate organic material (POM). Open diamond: grazer; open square: shredder; open circle: filter feeder; open triangle: predator; and open reverse-triangle: other invertebrates. Filled and open stars are demersal fish (goby) and other fishes, respectively

\section{Fig. 2.}

Biplot for the bulk stable carbon and nitrogen isotope ratios $\left(\delta^{13} \mathrm{C}_{\text {Bulk }}\right.$ and $\delta^{15} \mathrm{~N}_{\text {Bulk, }}$ respectively) of animals and their potential food sources collected in May 2012. The symbols are the same as described in Fig. 1

\section{Fig. 3.}

Biplot for the stable nitrogen isotope ratios of glutamic acid $\left(\delta^{15} \mathrm{~N}_{\mathrm{Glu}}\right)$ and phenylalanine ( $\left.\delta^{15} \mathrm{~N}_{\mathrm{Phe}}\right)$ of animals and their potential food sources, collected in November 2011. Aquatic and terrestrial baselines $(\mathrm{TL}=1)$ are indicated as solid lines (aquatic: $\delta^{15} \mathrm{~N}_{\mathrm{Glu}}-\delta^{15} \mathrm{~N}_{\text {Phe }}=$ +3.4; terrestrial C3: $\delta^{15} \mathrm{~N}_{\text {Glu }}-\delta^{15} \mathrm{~N}_{\text {Phe }}=-8.4$; Chikaraishi et al. 2009, 2010). Stepwise enrichments of $\delta^{15} \mathrm{~N}_{\text {Glu }}\left(+8.0 \%\right.$ ) and $\delta^{15} \mathrm{~N}_{\text {Phe }}(+0.4 \%$ ) along with trophic levels are shown as dashed $(\mathrm{TL}=2)$ and dotted $(\mathrm{TL}=3)$ lines for both aquatic and terrestrial food chains. The symbols are the same as described in Fig. 1 
Fig. 4.

Biplot for the stable nitrogen isotope ratios of glutamic acid $\left(\delta^{15} \mathrm{~N}_{\mathrm{Glu}}\right)$ and phenylalanine $\left(\delta^{15} \mathrm{~N}_{\text {Phe}}\right)$ of animals and their potential food sources, collected in May 2012. The symbols are the same as described in Fig. 1 and 3

\section{Fig. 5.}

a) Periphyton contribution to animals relative to terrestrial C3 litter (\%), estimated using a SIAA based two-source mixing model (see Eq. 4). Periphyton contribution to periphyton $(n=$ 13) and C3 litter $(n=7)$ were fixed at $100 \%$ and $0 \%$, respectively. Grazer: $G(n=9)$; predator: P (dragonfly: $n=4$; stonefly: $n=18$; dobsonfly: $n=5)$; other invertebrates: $\mathrm{O}(n=4)$; filter feeder: F ( $n=8)$; shredder: S $(n=5)$; goby $(n=10)$; and other fishes $(n=6)$; and b) Trophic position of animals based on the mixing proportion of aquatic (periphyton) and terrestrial (C3 litter) resources estimated using a SIAA based two-source mixing model (see Eq. 5). The box and bar depict inter-quartile (Q1 and Q3) and median, respectively. The whisker represents the most extreme data point that is no more than 1.5-fold the inter-quartile range. Outliers are shown where applicable

\section{Fig. 6.}

Biplot for the trophic positions estimated using the bulk method (Eq. 2-3) vs. those estimated using the SIAA method (Eq. 4-5) in a) November 2011 and b) May 2012. The symbols are the same as described in Fig. 1

\section{Fig. 7.}

Two-dimensional food web structure in stream ecosystems estimated from the stable nitrogen isotope ratios of glutamic acid and phenylalanine. The symbols are the same as described in 
75 Fig. 1; periphyton: $n=13$; terrestrial C3 litter: $n=7$; grazer: $n=9$; shredder: $n=5$; filter

76 feeder: $n=8$; other invertebrates: $n=4$; predator: $n=27$; demarsal fish (goby): $n=10$; and other fishes: $n=6$. The bars indicate standard deviations 


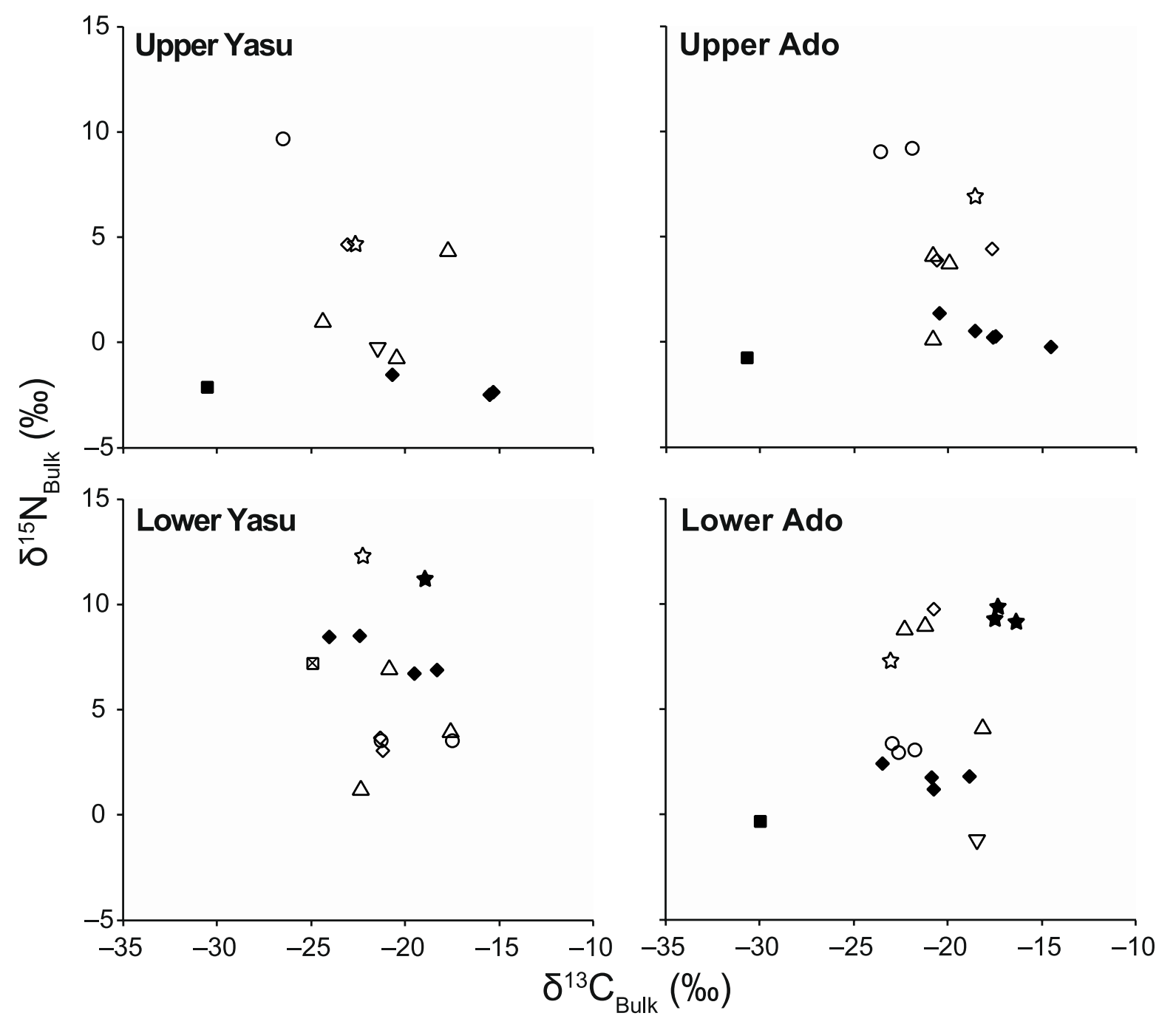

79

Figure 1

81 


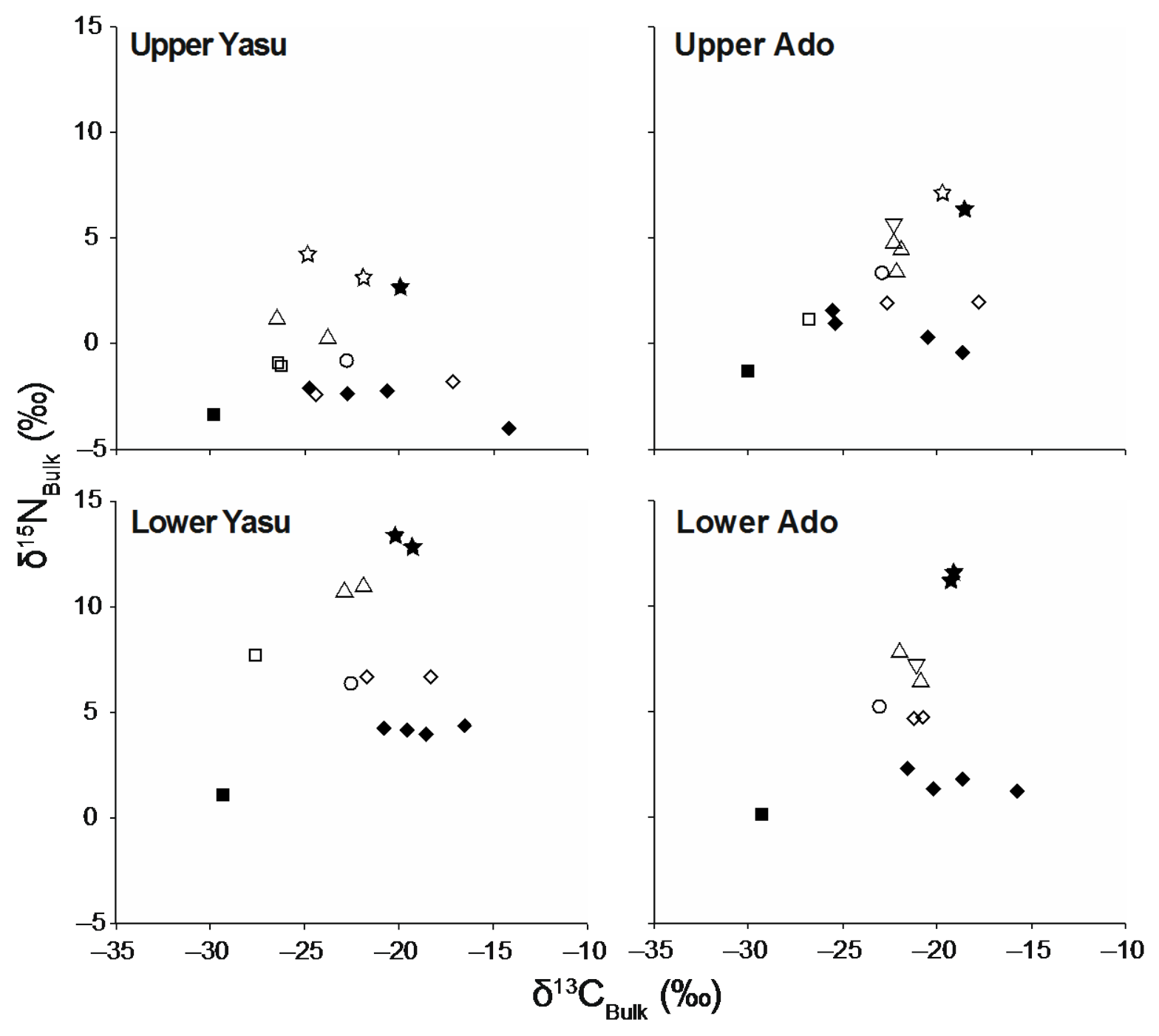

82

Figure 2

84 


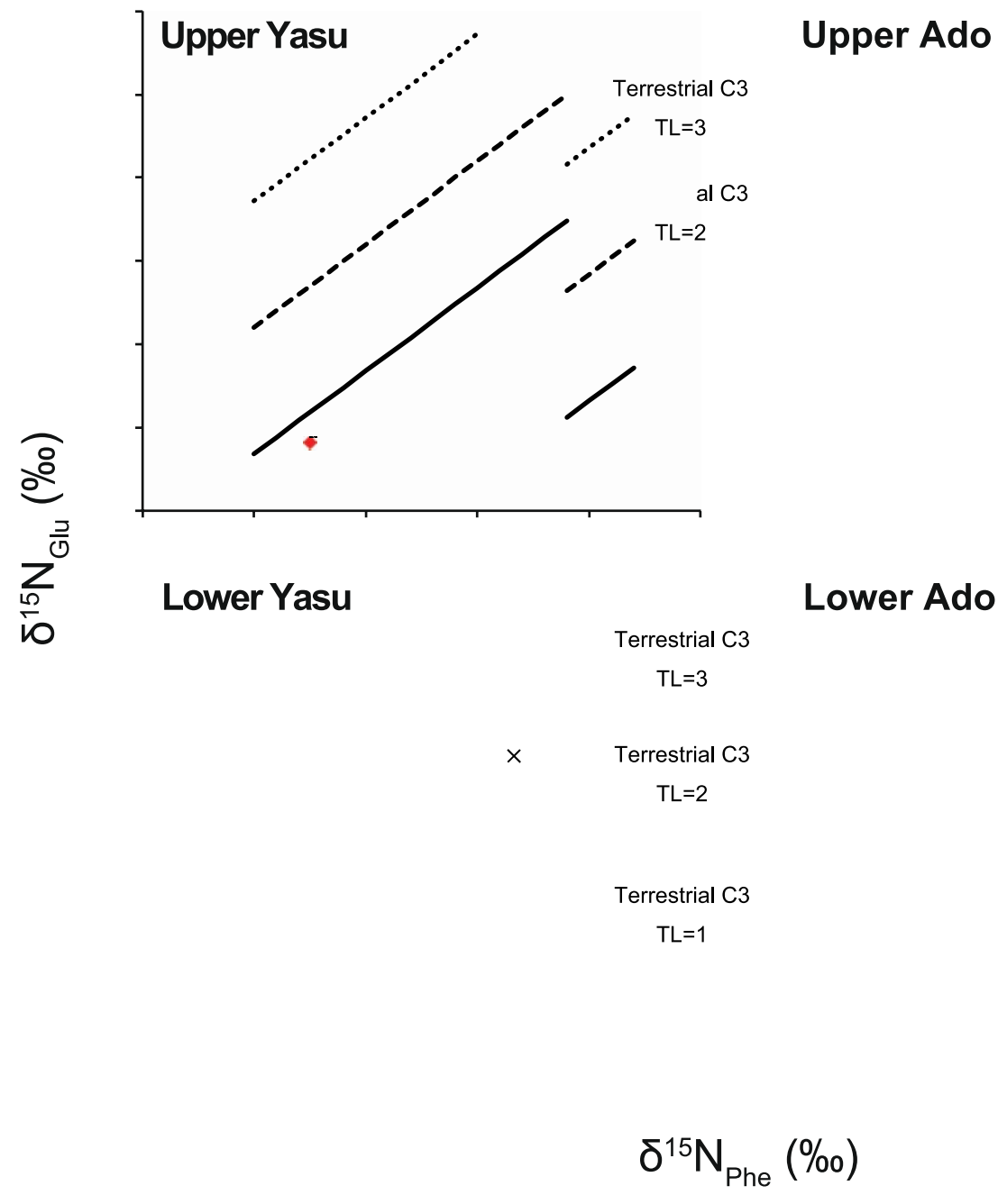

Figure 3

87 


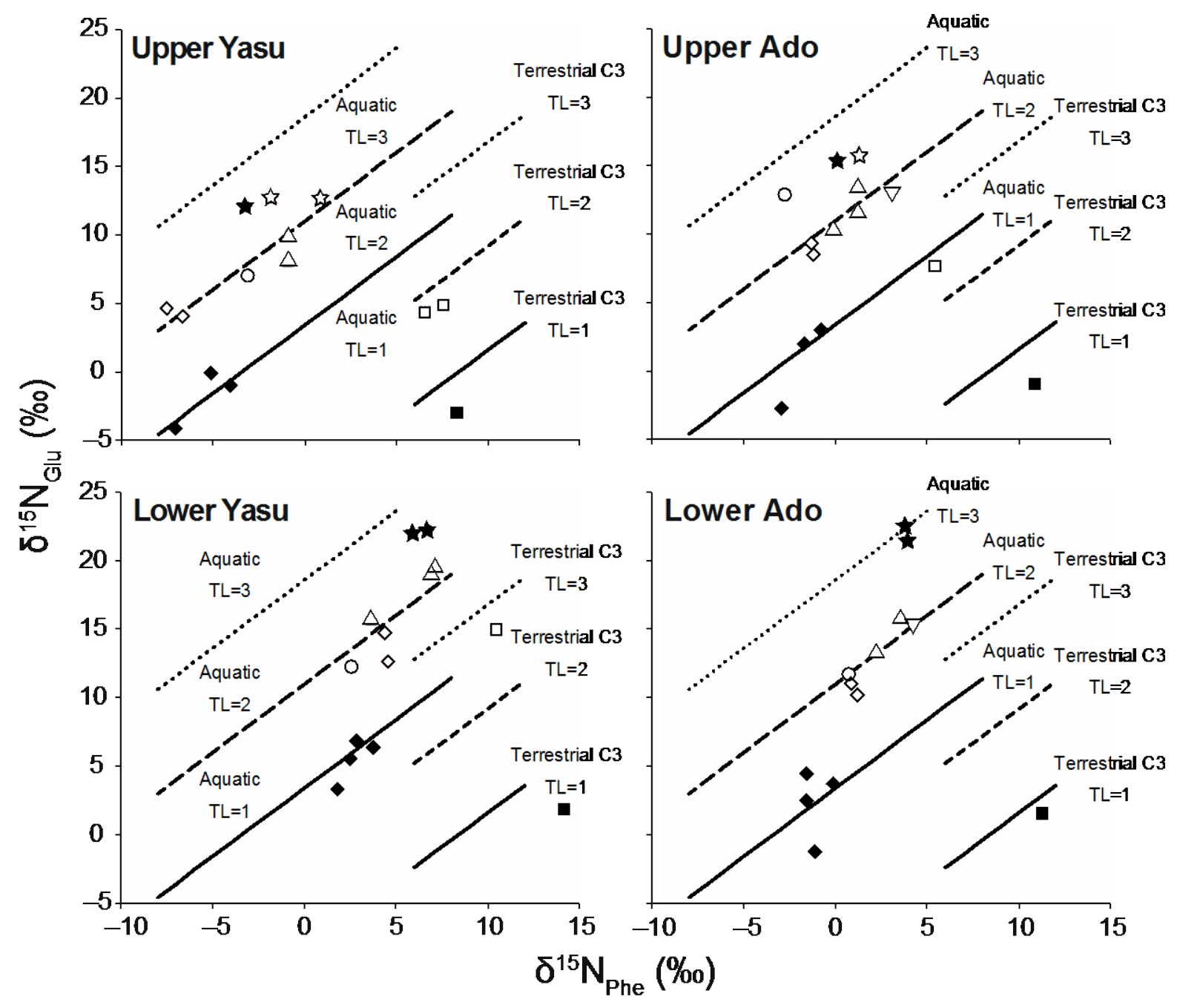

88

Figure 4 

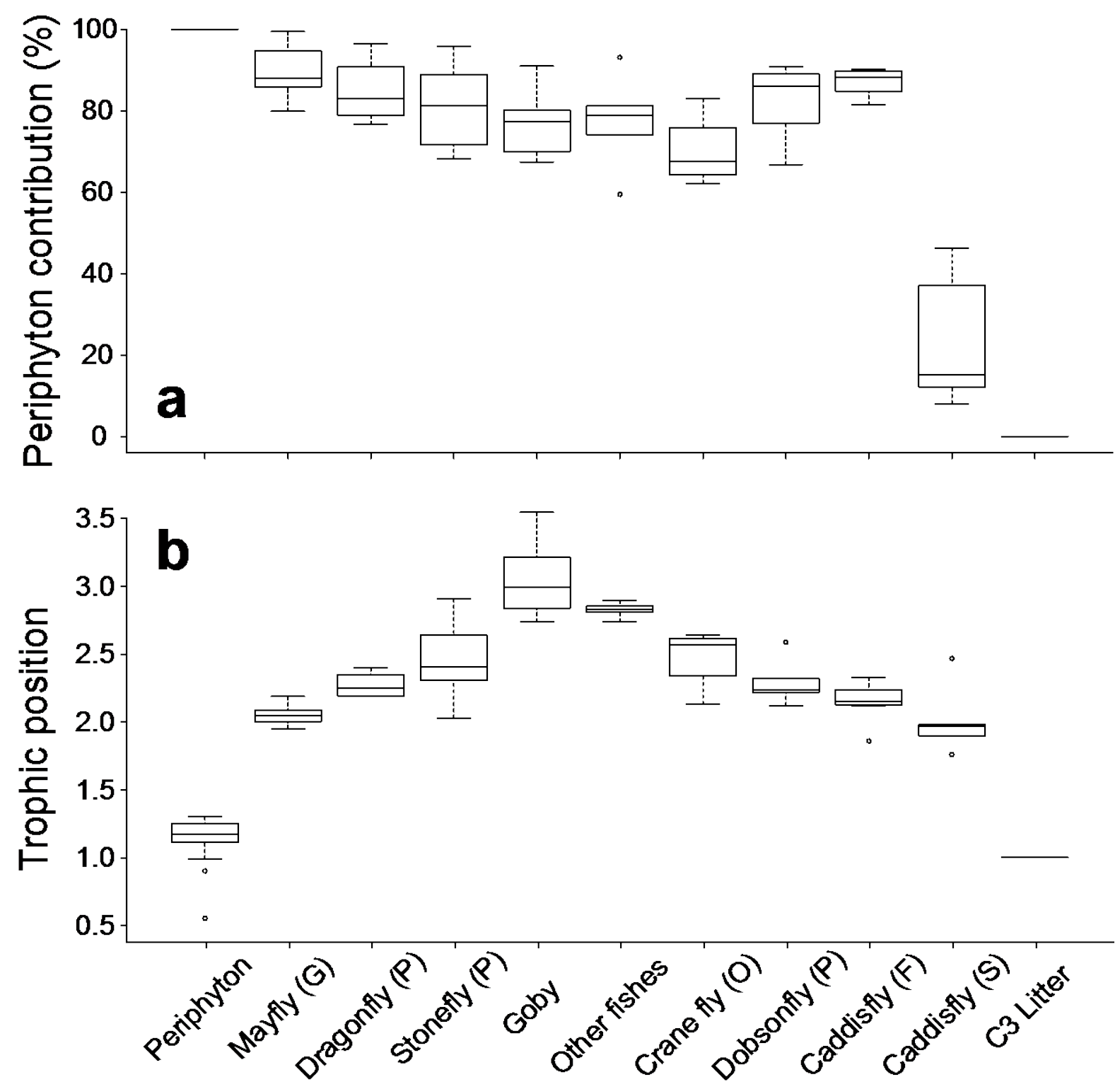

$92 \quad$ Figure 5 


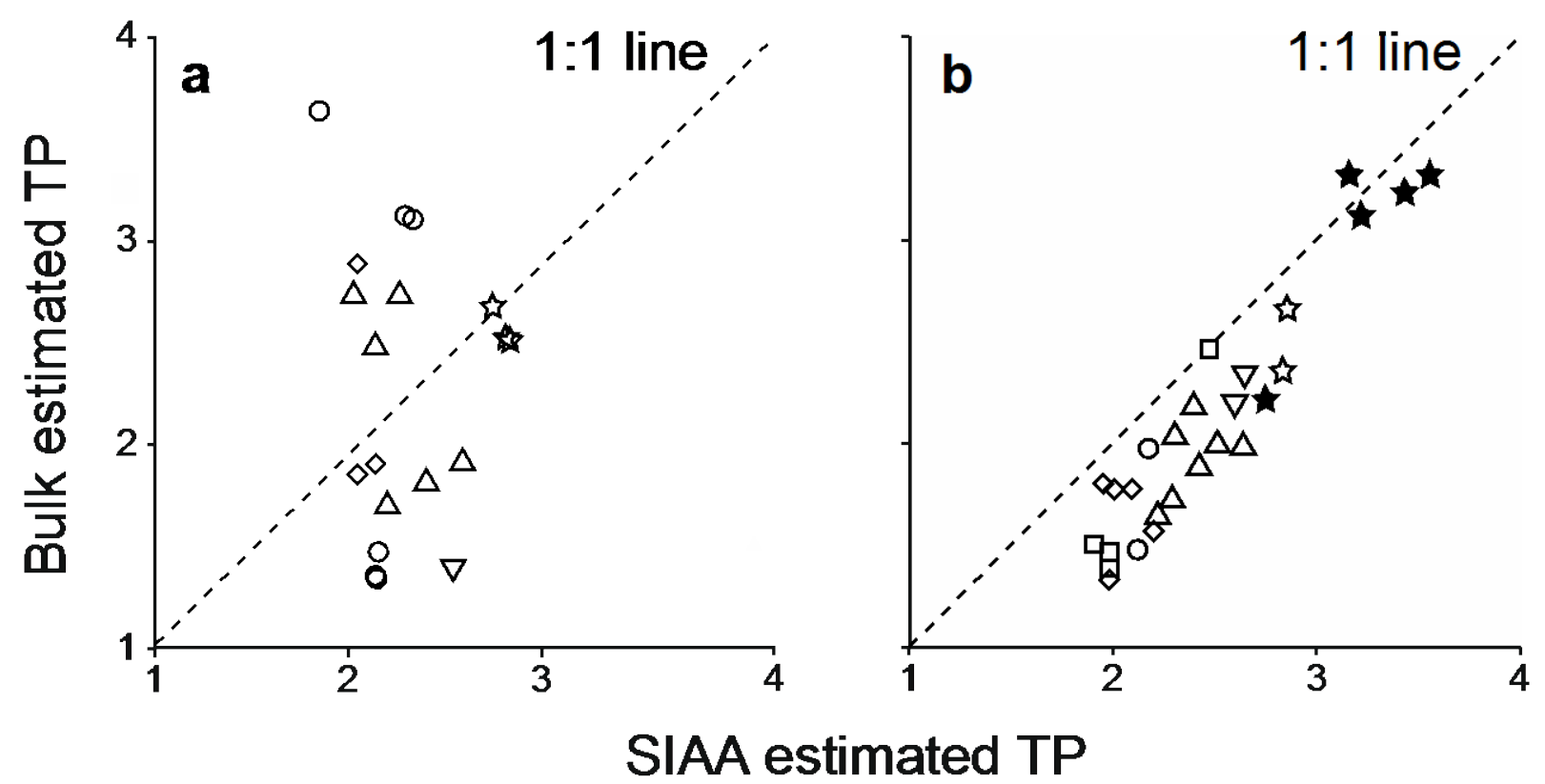

Figure 6 


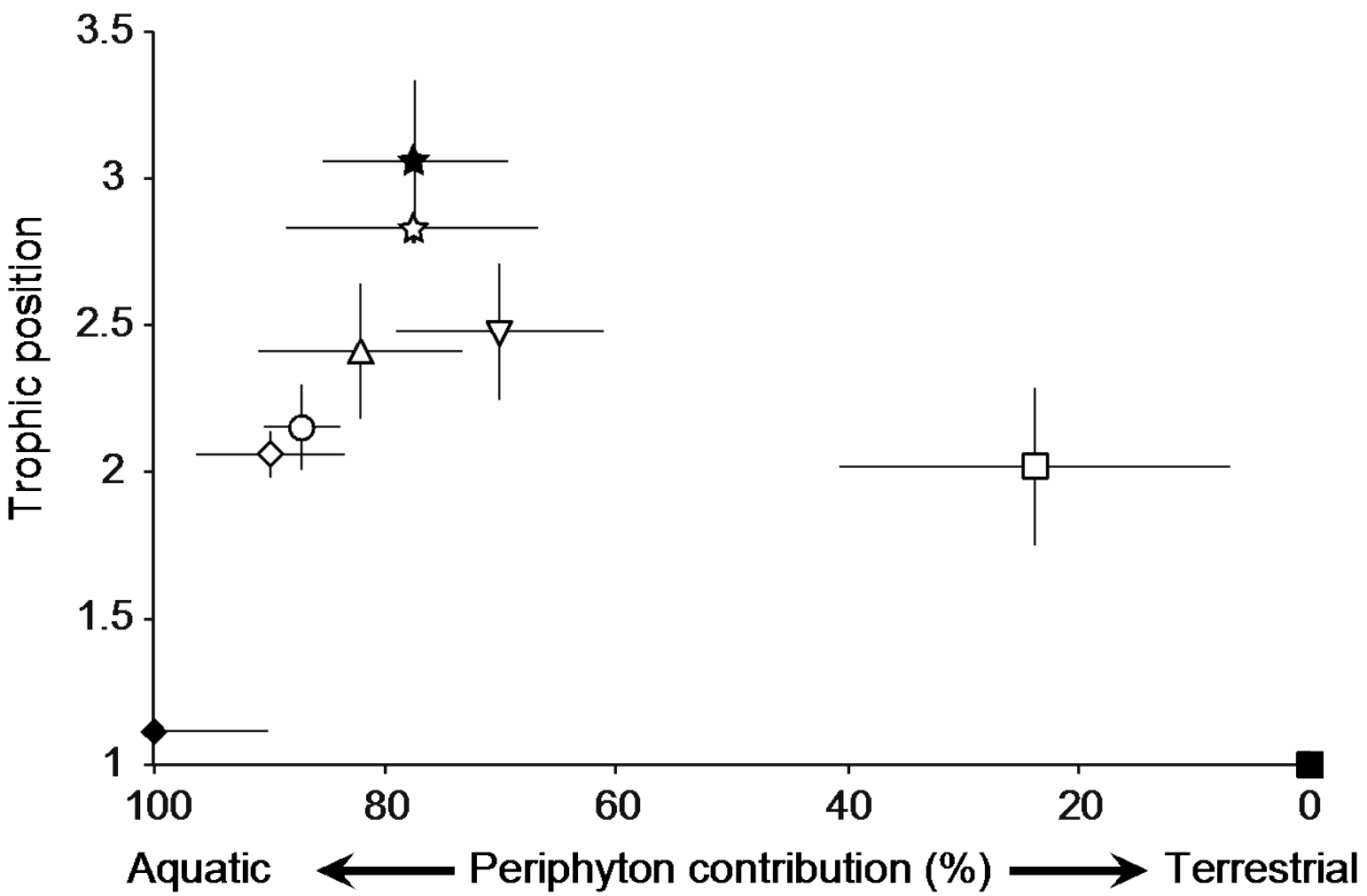

Figure 7 


\section{Stable nitrogen isotopic composition of amino acids reveals}

\section{food web structure in stream ecosystems}

Naoto F. Ishikawa ${ }^{1,4^{*}}$, Yoshikazu Kato ${ }^{1}$, Hiroyuki Togashi ${ }^{2,5}$, Mayumi Yoshimura ${ }^{3}$, Chikage Yoshimizu $^{1}$, Noboru Okuda ${ }^{1}$, Ichiro Tayasu ${ }^{1}$

${ }^{1}$ Center for Ecological Research, Kyoto University, 2-509-3 Hirano, Otsu, Shiga 520-2113, Japan

${ }^{2}$ Field Science Education and Research Center, Kyoto University, Oiwake-cho, Kitashirakawa, Sakyo, Kyoto 606-8502, Japan

${ }^{3}$ Kansai Research Center, Forestry and Forest Products Research Institute, 68 Nagaikyutaroh, Momoyama, Fushimi, Kyoto, 612-0855 Japan

${ }^{4}$ Present address: Japan Agency for Marine-Earth Science and Technology, 2-15

Natsushima-cho, Yokosuka, Kanagawa 237-0061, Japan

${ }^{5}$ Present address: Tohoku National Fisheries Research Institute, Fisheries Research Agency,

3-27-5, Shinhama-cho, Shiogama, Miyagi 985-0001, Japan

${ }^{*}$ Corresponding author.

E-mail: ishikawan@jamstec.go.jp

Running head: Amino acid $\delta^{15} \mathrm{~N}$ of stream animals 


\section{Appendices}

Source contribution to an animal (i.e., Eq. 2 and 4) is algebraically induced using two-isotope and two-source mixing model as follows: if $\mathrm{X}$ and

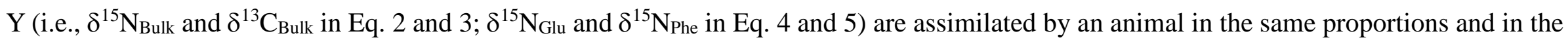
same trophic transfer pathways, then:

$\delta \mathrm{X}[\mathrm{A}]=f\left\{\delta \mathrm{X}[\mathrm{P}]+\Delta_{\mathrm{X}}(\mathrm{TP}-1)\right\}+(1-f)\left\{\delta \mathrm{X}[\mathrm{L}]+\Delta_{\mathrm{X}}(\mathrm{TP}-1)\right\}$
$\delta \mathrm{Y}[\mathrm{A}]=f\left\{\delta \mathrm{Y}[\mathrm{P}]+\Delta_{\mathrm{Y}}(\mathrm{TP}-1)\right\}+(1-f)\left\{\delta \mathrm{Y}[\mathrm{L}]+\Delta_{\mathrm{Y}}(\mathrm{TP}-1)\right\}$

where $0 \leq f \leq 1$ and $\delta \mathrm{X}[\mathrm{A}], \delta \mathrm{Y}[\mathrm{A}], \delta \mathrm{X}[\mathrm{L}], \delta \mathrm{Y}[\mathrm{L}], \delta \mathrm{X}[\mathrm{P}]$, and $\delta \mathrm{Y}[\mathrm{P}]$ are $\delta \mathrm{X}$ and $\delta \mathrm{Y}$ of animal [A], those of C3 litter [L], and those of periphyton [P] in each site, respectively. $\Delta_{\mathrm{X}}$ and $\Delta_{\mathrm{Y}}$ are trophic enrichment factors for $\delta \mathrm{X}$ and $\delta \mathrm{Y}$, respectively. TP is trophic position of animal [A]. If both $\Delta \mathrm{x}$ and $\Delta \mathrm{Y}$ are not zero, and $\mathrm{TP}$ is larger than 1 , then:

$f\left(\frac{\delta \mathrm{X}[\mathrm{P}]-\delta \mathrm{X}[\mathrm{L}]}{\Delta_{\mathrm{X}}(\mathrm{TP}-1)}-\frac{\delta \mathrm{Y}[\mathrm{P}]-\delta \mathrm{Y}[\mathrm{L}]}{\Delta_{\mathrm{Y}}(\mathrm{TP}-1)}\right)=\frac{\delta \mathrm{X}[\mathrm{A}]-\delta \mathrm{X}[\mathrm{L}]}{\Delta_{\mathrm{X}}(\mathrm{TP}-1)}-\frac{\delta \mathrm{Y}[\mathrm{A}]-\delta \mathrm{Y}[\mathrm{L}]}{\Delta_{\mathrm{Y}}(\mathrm{TP}-1)}$

Therefore, $f$ is finally represented regardless of TP of animal $[\mathrm{A}]$ as: 
$f=\frac{\frac{\delta \mathrm{X}[\mathrm{A}]-\delta \mathrm{X}[\mathrm{L}]}{\Delta \mathrm{X}}-\frac{\delta \mathrm{Y}[\mathrm{A}]-\delta \mathrm{Y}[\mathrm{L}]}{\Delta \mathrm{Y}}}{\frac{\delta \mathrm{X}[\mathrm{P}]-\delta \mathrm{X}[\mathrm{L}]}{\Delta \mathrm{X}}-\frac{\delta \mathrm{Y}[\mathrm{P}]-\delta \mathrm{Y}[\mathrm{L}]}{\Delta \mathrm{Y}}}$

TP of animal [A] (i.e., Eq. 3 and 5) is induced as:

$\Delta_{\mathrm{X}} \mathrm{TP}=f(\delta \mathrm{X}[\mathrm{A}]-\delta \mathrm{X}[\mathrm{P}])+(1-f)(\delta \mathrm{X}[\mathrm{A}]-\delta \mathrm{X}[\mathrm{L}])+\Delta_{\mathrm{X}}$

$\Delta \mathrm{Y} \mathrm{TP}=f(\delta \mathrm{Y}[\mathrm{A}]-\delta \mathrm{Y}[\mathrm{P}])+(1-f)(\delta \mathrm{Y}[\mathrm{A}]-\delta \mathrm{Y}[\mathrm{L}])+\Delta \mathrm{Y}$

If $\Delta_{\mathrm{X}}$ is not equal to $\Delta_{\mathrm{Y}}$, then:

$\mathrm{TP}=\frac{\delta \mathrm{X}[\mathrm{A}]-\delta \mathrm{Y}[\mathrm{A}]-\{f(\delta \mathrm{X}[\mathrm{P}]-\delta \mathrm{Y}[\mathrm{P}])+(1-f)(\delta \mathrm{X}[\mathrm{L}]-\delta \mathrm{Y}[\mathrm{L}])\}}{\Delta_{\mathrm{X}}-\Delta_{\mathrm{Y}}}+1$ 
Table A1.

Geographic information of the study sites

\begin{tabular}{|c|c|c|c|c|}
\hline & \multicolumn{2}{|l|}{ Yasu } & \multicolumn{2}{|l|}{ Ado } \\
\hline & Upper & Lower & Upper & Lower \\
\hline Latitude & $35^{\circ} 00^{\prime} 05^{\prime \prime} \mathrm{N}$ & $34^{\circ} 59^{\prime} 04^{\prime \prime} \mathrm{N}$ & $35^{\circ} 12^{\prime} 35^{\prime \prime} \mathrm{N}$ & $35^{\circ} 21^{\prime} 00^{\prime \prime} \mathrm{N}$ \\
\hline Longitude & $136^{\circ} 23^{\prime} 31^{\prime \prime} \mathrm{E}$ & $136^{\circ} 07^{\prime} 15^{\prime \prime} \mathrm{E}$ & $135^{\circ} 51^{\prime} 20^{\prime \prime} \mathrm{E}$ & $136^{\circ} 00^{\prime} 02^{\prime \prime} \mathrm{E}$ \\
\hline Watershed area $\left(\mathrm{km}^{2}\right)$ & 4.2 & 294.7 & 25.4 & 298.5 \\
\hline Mean width (m) & 8.2 & 60.8 & 17.7 & 31.0 \\
\hline Elevation (m a.s.l.) & 508 & 145 & 435 & 108 \\
\hline $\begin{array}{l}\text { Canopy cover (\%) in } \\
\text { November } 2011\end{array}$ & 48.4 & 13.8 & 68.1 & 12.2 \\
\hline $\begin{array}{l}\text { Canopy cover (\%) in } \\
\text { May } 2012\end{array}$ & 58.5 & 14.0 & 78.2 & 19.1 \\
\hline Substrate & Cobble & Cobble & Cobble & Cobble/Sand \\
\hline
\end{tabular}


Table A2.

Analysis of variance table for periphyton contributions (relative to C3 litter) to animals estimated using a SIAA based two-source mixing model

\begin{tabular}{lrrrrr}
\hline & Df & \multicolumn{1}{c}{ Sum Sq } & Mean Sq & $F$ value & $p$ value \\
\hline Season & 1 & 1135 & 1135 & 14.6 & $<0.001$ \\
River & 1 & 2248 & 2248 & 28.8 & $<0.001$ \\
Site & 1 & 51 & 50 & 0.6 & 0.424 \\
Animal group & 8 & 14426 & 1803 & 23.1 & $<0.001$ \\
Residuals & 57 & 4446 & 78 & & \\
\hline
\end{tabular}


Table A3.

Analysis of variance table for the trophic positions of animals estimated using a SIAA based two-source mixing model

\begin{tabular}{lrrrrr}
\hline & Df & Sum Sq & & Mean Sq & \multicolumn{2}{c}{$F$ value } & \multicolumn{2}{c}{$p$ value } \\
\hline Season & 1 & 0.33 & 0.33 & 8.7 & 0.005 \\
River & 1 & 0.05 & 0.05 & 1.4 & 0.235 \\
Site & 1 & 0.24 & 0.24 & 6.3 & 0.015 \\
Animal group & 8 & 7.60 & 0.95 & 25.2 & $<0.001$ \\
Residuals & 57 & 2.15 & 0.04 & & \\
\hline
\end{tabular}




\section{Table A4.}

Full dataset analyzed in this study. N/A: Not available

\begin{tabular}{|c|c|c|c|c|c|c|c|c|c|c|c|c|}
\hline \multirow[b]{2}{*}{ River } & \multirow[b]{2}{*}{ Site } & \multirow[b]{2}{*}{ Specimen } & \multirow[b]{2}{*}{ Scientific name } & \multirow[b]{2}{*}{ FFG } & \multicolumn{4}{|c|}{ SIAA } & \multicolumn{4}{|c|}{ Bulk } \\
\hline & & & & & $\begin{array}{l}\delta^{15} \mathrm{~N}_{\mathrm{Glu}} \\
(\%)\end{array}$ & $\begin{array}{l}\delta^{15} \mathrm{~N}_{\text {Phe }} \\
(\%)\end{array}$ & $\begin{array}{l}\text { Periphyton contribution } \\
\text { (\%) }\end{array}$ & $\begin{array}{l}\text { Trophic } \\
\text { position }\end{array}$ & $\begin{array}{l}\delta^{15} \mathrm{~N}_{\text {Bulk }} \\
(\%)\end{array}$ & $\begin{array}{l}\delta^{13} \mathrm{C}_{\text {Bulk }} \\
(\%)\end{array}$ & $\begin{array}{l}\text { Periphyton contribution } \\
\text { (\%) }\end{array}$ & $\begin{array}{l}\text { Trophic } \\
\text { position }\end{array}$ \\
\hline Yasu & Upper & Periphyton & & & -0.88 & -2.51 & 96.57 & 0.90 & -2.46 & -15.51 & & \\
\hline Yasu & Upper & Periphyton & & & -0.17 & -2.21 & 94.60 & 0.99 & -2.42 & -15.35 & & \\
\hline Yasu & Upper & Periphyton & & & 1.01 & -4.03 & 108.83 & & -1.55 & -20.71 & & \\
\hline Ado & Upper & Periphyton & & & 4.63 & 1.12 & 82.81 & 1.28 & 1.38 & -20.49 & & \\
\hline Ado & Upper & Periphyton & & & 1.13 & -3.16 & 116.70 & & 0.25 & -17.43 & & \\
\hline Ado & Upper & Periphyton & & & 4.38 & 1.65 & 78.36 & 1.25 & 0.54 & -18.55 & & \\
\hline Ado & Upper & Periphyton & & & 0.65 & -3.48 & 119.07 & & -0.24 & -14.55 & & \\
\hline Ado & Upper & Periphyton & & & 1.07 & -1.51 & 103.07 & & 0.20 & -17.61 & & \\
\hline Yasu & Lower & Periphyton & & & 8.73 & 6.60 & & & 6.89 & -18.35 & & \\
\hline Yasu & Lower & Periphyton & & & 13.23 & 9.08 & & & 8.44 & -24.02 & & \\
\hline Yasu & Lower & Periphyton & & & 10.61 & 4.89 & & & 6.73 & -19.53 & & \\
\hline Yasu & Lower & Periphyton & & & 12.47 & 6.62 & & & 8.52 & -22.42 & & \\
\hline Ado & Lower & Periphyton & & & 6.45 & 1.25 & 84.47 & 1.27 & 2.39 & -23.48 & & \\
\hline Ado & Lower & Periphyton & & & 3.39 & -1.35 & 104.13 & & 1.71 & -20.86 & & \\
\hline Ado & Lower & Periphyton & & & 5.20 & -2.12 & 111.00 & & 1.21 & -20.77 & & \\
\hline Ado & Lower & Periphyton & & & 4.32 & -0.84 & 100.40 & & 1.81 & -18.86 & & \\
\hline Yasu & Upper & Periphyton & & & -1.02 & -4.08 & 90.44 & 1.11 & -2.32 & -22.77 & & \\
\hline Yasu & Upper & Periphyton & & & -4.12 & -7.08 & 111.08 & & -4.03 & -14.19 & & \\
\hline Yasu & Upper & Periphyton & & & & & & & -2.21 & -20.62 & & \\
\hline Yasu & Upper & Periphyton & & & -0.11 & -5.15 & 98.48 & 1.21 & -2.13 & -24.80 & & \\
\hline Ado & Upper & Periphyton & & & 3.06 & -0.84 & 93.10 & 1.30 & 0.99 & -25.37 & & \\
\hline
\end{tabular}


Table A4 (continued).

\begin{tabular}{|c|c|c|c|c|c|c|c|c|c|c|c|c|c|}
\hline \multirow[b]{2}{*}{ Season } & \multirow[b]{2}{*}{ River } & \multirow[b]{2}{*}{ Site } & \multirow[b]{2}{*}{ Specimen } & \multirow[b]{2}{*}{ Scientific name } & \multirow[b]{2}{*}{ FFG } & \multicolumn{4}{|c|}{ SIAA } & \multicolumn{4}{|c|}{ Bulk } \\
\hline & & & & & & $\begin{array}{l}\delta^{15} \mathrm{~N}_{\text {Glu }} \\
(\% \text { ) }\end{array}$ & $\begin{array}{l}\delta^{15} \mathrm{~N}_{\text {Phe }} \\
(\%)\end{array}$ & $\begin{array}{l}\text { Periphyton } \\
\text { contribution (\%) }\end{array}$ & $\begin{array}{l}\text { Trophic } \\
\text { position }\end{array}$ & $\begin{array}{l}\delta^{15} \mathrm{~N}_{\text {Bulk }} \\
(\%)\end{array}$ & $\begin{array}{l}\delta^{13} \mathrm{C}_{\text {Bulk }} \\
(\%)\end{array}$ & $\begin{array}{l}\text { Periphyton } \\
\text { contribution (\%) }\end{array}$ & $\begin{array}{l}\text { Trophic } \\
\text { position }\end{array}$ \\
\hline May & Ado & Upper & Periphyton & & & 2.03 & -1.72 & 99.63 & 1.16 & 0.30 & -20.46 & & \\
\hline May & Ado & Upper & Periphyton & & & & & & & 1.57 & -25.55 & & \\
\hline May & Ado & Upper & Periphyton & & & -2.75 & -2.94 & 107.27 & & -0.36 & -18.62 & & \\
\hline May & Yasu & Lower & Periphyton & & & 6.34 & 3.77 & 91.20 & 1.14 & 4.37 & -16.55 & & \\
\hline May & Yasu & Lower & Periphyton & & & 3.35 & 1.78 & 107.12 & & 3.97 & -18.56 & & \\
\hline May & Yasu & Lower & Periphyton & & & 6.80 & 2.84 & 99.42 & 1.17 & 4.24 & -20.81 & & \\
\hline May & Yasu & Lower & Periphyton & & & 5.49 & 2.45 & 102.26 & & 4.19 & -19.55 & & \\
\hline May & Ado & Lower & Periphyton & & & 2.44 & -1.56 & 105.62 & & 1.27 & -15.79 & & \\
\hline May & Ado & Lower & Periphyton & & & 3.77 & -0.13 & 92.75 & 1.18 & 2.35 & -21.60 & & \\
\hline May & Ado & Lower & Periphyton & & & 4.49 & -1.53 & 104.38 & & 1.38 & -20.20 & & \\
\hline May & Ado & Lower & Periphyton & & & -1.19 & -1.16 & 99.07 & 0.55 & 1.83 & -18.69 & & \\
\hline November & Yasu & Upper & Mayfly & Heptageniidae spp. & Grazer & 6.14 & -3.76 & 108.75 & & 4.66 & -23.02 & 38.94 & 3.03 \\
\hline November & Ado & Upper & Mayfly & Heptageniidae spp. & Grazer & 11.59 & 1.10 & 85.82 & 2.15 & 4.40 & -17.67 & 103.93 & \\
\hline November & Ado & Upper & Mayfly & Heptageniidae spp. & Grazer & 10.82 & 1.78 & 79.93 & 2.05 & 3.90 & -20.65 & 78.77 & 2.00 \\
\hline November & Yasu & Lower & Mayfly & Heptageniidae spp. & Grazer & 17.35 & 8.02 & & & 2.99 & -21.18 & 100.00 & \\
\hline November & Yasu & Lower & Mayfly & Heptageniidae spp. & Grazer & 17.75 & 8.04 & & & 3.68 & -21.36 & 100.00 & \\
\hline November & Ado & Lower & Mayfly & Baetis spp. & Grazer & 12.98 & 0.29 & 94.76 & 2.04 & 9.76 & -20.78 & 94.23 & 3.31 \\
\hline May & Yasu & Upper & Mayfly & Heptageniidae spp. & Grazer & 4.64 & -7.52 & 117.47 & & -2.42 & -24.44 & 45.87 & 1.25 \\
\hline May & Yasu & Upper & Mayfly & Heptageniidae spp. & Grazer & 4.09 & -6.62 & 110.72 & & -1.84 & -17.18 & 108.67 & \\
\hline May & Ado & Upper & Mayfly & Heptageniidae spp. & Grazer & 8.55 & -1.21 & 98.19 & 1.98 & 1.98 & -22.64 & 99.43 & 1.40 \\
\hline May & Ado & Upper & Mayfly & Heptageniidae spp. & Grazer & 9.37 & -1.34 & 99.47 & 2.07 & 1.99 & -17.76 & 172.62 & \\
\hline
\end{tabular}


Table A4 (continued).

\begin{tabular}{|c|c|c|c|c|c|c|c|c|c|c|c|c|}
\hline \multirow[b]{2}{*}{ River } & \multirow[b]{2}{*}{ Site } & \multirow[b]{2}{*}{ Specimen } & \multirow[b]{2}{*}{ Scientific name } & \multirow[b]{2}{*}{ FFG } & \multicolumn{4}{|c|}{ SIAA } & \multicolumn{4}{|c|}{ Bulk } \\
\hline & & & & & $\begin{array}{l}\delta^{15} \mathrm{~N}_{\text {Glu }} \\
(\% \text { ) }\end{array}$ & $\begin{array}{l}\delta^{15} \mathrm{~N}_{\text {Phe }} \\
(\%)\end{array}$ & $\begin{array}{l}\text { Periphyton contribution } \\
\text { (\%) }\end{array}$ & $\begin{array}{l}\text { Trophic } \\
\text { position }\end{array}$ & $\begin{array}{l}\delta^{15} \mathrm{~N}_{\text {Bulk }} \\
(\%)\end{array}$ & $\begin{array}{l}\delta^{13} \mathrm{C}_{\text {Bulk }} \\
(\% \text { ) }\end{array}$ & $\begin{array}{l}\text { Periphyton contribution } \\
\text { (\%) }\end{array}$ & $\begin{array}{l}\text { Trophic } \\
\text { position }\end{array}$ \\
\hline Yasu & Lower & Mayfly & Heptageniidae spp. & Grazer & 12.61 & 4.54 & 87.26 & 1.95 & 6.65 & -21.77 & 56.64 & 2.12 \\
\hline Yasu & Lower & Mayfly & Baetis spp. & Grazer & 14.69 & 4.28 & 90.43 & 2.19 & 6.71 & -18.34 & 87.50 & 1.86 \\
\hline Ado & Lower & Mayfly & Heptageniidae spp. & Grazer & 10.25 & 1.17 & 84.85 & 2.00 & 4.73 & -21.20 & 68.64 & 2.01 \\
\hline Ado & Lower & Mayfly & Heptageniidae spp. & Grazer & 10.99 & 0.83 & 87.94 & 2.09 & 4.76 & -20.82 & 72.29 & 2.00 \\
\hline Yasu & Upper & Dragon fly & Gomphidae spp. & Predator & 9.30 & 0.63 & 76.64 & 2.20 & 1.06 & -24.37 & 35.59 & 1.96 \\
\hline Ado & Upper & Dragon fly & Gomphidae spp. & Predator & 13.61 & 1.31 & 84.93 & 2.40 & 3.83 & -19.91 & 85.42 & 1.95 \\
\hline Yasu & Lower & Dragon fly & Gomphidae spp. & Predator & 15.63 & 4.50 & & & 7.00 & -20.89 & 100.00 & \\
\hline Ado & Lower & Dragon fly & Gomphidae spp. & Predator & 13.64 & 2.01 & 81.24 & 2.19 & 4.18 & -18.15 & 148.69 & \\
\hline Yasu & Lower & Dragon fly & Gomphidae spp. & Predator & 15.79 & 3.62 & 96.58 & 2.30 & 7.48 & -22.42 & 48.94 & 2.43 \\
\hline Yasu & Upper & Stonefly & Kamimuria tibialis & Predator & 10.44 & -2.45 & 100.44 & & -0.65 & -20.52 & 63.65 & 1.49 \\
\hline Yasu & Upper & Stonefly & Chloroperlidae spp. & Predator & 8.98 & -0.90 & 88.14 & 2.14 & 4.47 & -17.80 & 73.61 & 3.01 \\
\hline Ado & Upper & Stonefly & Kamimuria tibialis & Predator & 13.48 & 1.03 & 87.18 & 2.38 & 0.11 & -20.88 & 84.59 & 0.86 \\
\hline Ado & Upper & Stonefly & Kamimuria tibialis & Predator & 14.50 & 2.13 & 78.52 & 2.51 & & & & \\
\hline Ado & Upper & Stonefly & Kamimuria tibialis & Predator & 13.45 & 1.77 & 81.11 & 2.38 & & & & \\
\hline Ado & Upper & Stonefly & Kamimuria tibialis & Predator & 14.82 & 1.56 & 83.36 & 2.55 & & & & \\
\hline Ado & Upper & Stonefly & Kamimuria tibialis & Predator & 13.28 & 0.81 & 88.98 & 2.36 & & & & \\
\hline Ado & Upper & Stonefly & Kamimuria tibialis & Predator & 12.88 & 0.23 & 93.57 & 2.31 & & & & \\
\hline Ado & Upper & Stonefly & Paragnetina tinctipennis & Predator & 17.34 & 0.18 & 95.80 & 2.87 & & & & \\
\hline Yasu & Lower & Stonefly & Kamimuria tibialis & Predator & 20.51 & 7.84 & & & 3.99 & -17.61 & 100.00 & \\
\hline Yasu & Lower & Stonefly & Kamimuria tibialis & Predator & 19.78 & 7.50 & & & 1.24 & -22.37 & 100.00 & \\
\hline Yasu & Lower & Amphipods & Gammarus nipponensis & Predator & 20.63 & 6.90 & & & & & & \\
\hline
\end{tabular}


Table A4 (continued).

\begin{tabular}{|c|c|c|c|c|c|c|c|c|c|c|c|c|}
\hline \multirow[b]{2}{*}{ River } & \multirow[b]{2}{*}{ Site } & \multirow[b]{2}{*}{ Specimen } & \multirow[b]{2}{*}{ Scientific name } & \multirow[b]{2}{*}{ FFG } & \multicolumn{4}{|c|}{ SIAA } & \multicolumn{4}{|c|}{ Bulk } \\
\hline & & & & & $\begin{array}{l}\delta^{15} \mathrm{~N}_{\mathrm{Glu}} \\
(\%)\end{array}$ & $\begin{array}{l}\delta^{15} \mathrm{~N}_{\text {Phe }} \\
(\%)\end{array}$ & $\begin{array}{l}\text { Periphyton contribution } \\
\text { (\%) }\end{array}$ & $\begin{array}{l}\text { Trophic } \\
\text { position }\end{array}$ & $\begin{array}{l}\delta^{15} \mathrm{~N}_{\text {Bulk }} \\
(\%)\end{array}$ & $\begin{array}{l}\delta^{13} \mathrm{C}_{\text {Bulk }} \\
(\%)\end{array}$ & $\begin{array}{l}\text { Periphyton contribution } \\
\text { (\%) }\end{array}$ & $\begin{array}{l}\text { Trophic } \\
\text { position }\end{array}$ \\
\hline Ado & Lower & Stonefly & Kamimuria tibialis & Predator & 12.71 & 0.92 & 89.60 & 2.03 & 8.85 & -22.30 & 76.17 & 3.16 \\
\hline Ado & Lower & Stonefly & Kamimuria tibialis & Predator & 14.63 & 0.80 & 91.32 & 2.26 & 9.05 & -21.21 & 90.47 & 3.13 \\
\hline Ado & Lower & Stonefly & Oyamia lugubris & Predator & 11.46 & -0.51 & 100.61 & & & & & \\
\hline Yasu & Upper & Stonefly & Niponiella limbatella & Predator & 8.17 & -0.92 & 70.80 & 2.29 & 0.31 & -23.85 & 45.48 & 2.05 \\
\hline Yasu & Upper & Stonefly & Niponiella limbatella & Predator & 9.98 & -0.95 & 71.65 & 2.51 & 1.29 & -26.50 & 20.07 & 2.35 \\
\hline Ado & Upper & Stonefly & Niponiella limbatella & Predator & 11.82 & 1.19 & 80.61 & 2.42 & 4.52 & -21.98 & 100.38 & \\
\hline Ado & Upper & Stonefly & Niponiella limbatella & Predator & 13.55 & 1.19 & 81.28 & 2.64 & 4.84 & -22.34 & 93.88 & 2.27 \\
\hline Yasu & Lower & Stonefly & Niponiella limbatella & Predator & 19.20 & 6.86 & 70.14 & 2.85 & 10.82 & -22.88 & 37.72 & 3.51 \\
\hline Yasu & Lower & Stonefly & Niponiella limbatella & Predator & 19.62 & 7.09 & 68.32 & 2.91 & 10.98 & -21.95 & 45.81 & 3.49 \\
\hline Ado & Lower & Stonefly & Chloroperlidae spp. & Predator & 13.36 & 2.21 & 77.71 & 2.39 & 6.51 & -20.93 & 67.12 & 2.54 \\
\hline Ado & Lower & Stonefly & Chloroperlidae spp. & Predator & 15.86 & 3.50 & 68.23 & 2.72 & 7.92 & -22.04 & 53.03 & 3.03 \\
\hline Yasu & Lower & Fish (Goby) & Rhinogobius kurodai & & 21.79 & 5.88 & & & 13.12 & & & \\
\hline Yasu & Lower & Fish (Goby) & Rhinogobius kurodai & & 19.86 & 5.06 & & & 11.22 & -18.95 & 100.00 & \\
\hline Ado & Lower & Fish (Goby) & Rhinogobius kurodai & & 20.21 & 2.79 & 77.58 & 3.03 & & & & \\
\hline Ado & Lower & Fish (Goby) & Rhinogobius kurodai & & 19.07 & 2.79 & 77.18 & 2.88 & 9.31 & -17.51 & 140.86 & \\
\hline Ado & Lower & Fish (Goby) & Rhinogobius kurodai & & 18.09 & 2.37 & 80.10 & 2.75 & 9.22 & -16.32 & 157.72 & \\
\hline Ado & Lower & Fish (Goby) & Rhinogobius kurodai & & 19.44 & 3.71 & 69.92 & 2.96 & 9.86 & -17.33 & 141.57 & \\
\hline Yasu & Upper & Fish (Goby) & Rhinogobius flumineus & & 12.03 & -3.26 & 89.16 & 2.74 & 2.69 & -19.95 & 74.84 & 2.74 \\
\hline Ado & Upper & Fish (Goby) & Rhinogobius flumineus & & 15.38 & 0.05 & 90.95 & 2.84 & 6.42 & -18.59 & 144.51 & \\
\hline Yasu & Lower & Fish (Goby) & Rhinogobius kurodai & & 22.32 & 6.66 & 73.19 & 3.22 & 12.82 & -19.32 & 65.64 & 3.85 \\
\hline Yasu & Lower & Fish (Goby) & Rhinogobius kurodai & & 21.97 & 5.94 & 79.25 & 3.15 & 13.39 & -20.19 & 56.59 & 4.10 \\
\hline
\end{tabular}


Table A4 (continued).

\begin{tabular}{|c|c|c|c|c|c|c|c|c|c|c|c|c|}
\hline \multirow[b]{2}{*}{ River } & \multirow[b]{2}{*}{ Site } & \multirow[b]{2}{*}{ Specimen } & \multirow[b]{2}{*}{ Scientific name } & \multirow[b]{2}{*}{ FFG } & \multicolumn{4}{|c|}{ SIAA } & \multicolumn{4}{|c|}{ Bulk } \\
\hline & & & & & $\begin{array}{l}\delta^{15} \mathrm{~N}_{\mathrm{Glu}} \\
(\%)\end{array}$ & $\begin{array}{l}\delta^{15} \mathrm{~N}_{\text {Phe }} \\
(\% \text { ) }\end{array}$ & $\begin{array}{l}\text { Periphyton } \\
\text { contribution (\%) }\end{array}$ & $\begin{array}{l}\text { Trophic } \\
\text { position }\end{array}$ & $\begin{array}{l}\delta^{15} \mathrm{~N}_{\text {Bulk }} \\
(\%)\end{array}$ & $\begin{array}{l}\delta^{13} \mathrm{C}_{\text {Bulk }} \\
(\%)\end{array}$ & $\begin{array}{l}\text { Periphyton } \\
\text { contribution (\%) }\end{array}$ & $\begin{array}{l}\text { Trophic } \\
\text { position }\end{array}$ \\
\hline Ado & Lower & Fish (Goby) & Rhinogobius kurodai & & 21.57 & 3.89 & 67.44 & 3.43 & 11.25 & -19.26 & 72.60 & 3.91 \\
\hline Ado & Lower & Fish (Goby) & Rhinogobius kurodai & & 22.54 & 3.75 & 68.95 & 3.55 & 11.63 & -19.12 & 73.09 & 4.02 \\
\hline Yasu & Upper & Fish (Trout) & Oncorhynchus masou ishikawae & & 14.18 & 1.21 & 74.13 & 2.81 & 4.68 & -22.65 & 41.35 & 3.04 \\
\hline Ado & Upper & Fish (Trout) & Oncorhynchus masou ishikawae & & 17.13 & 0.49 & 93.13 & 2.84 & 6.89 & -18.58 & 90.78 & 2.83 \\
\hline Ado & Upper & Fish (Minnow) & Rhynchocypris sp. & & 16.35 & 2.19 & 78.85 & 2.74 & 7.26 & -23.06 & 50.66 & 3.12 \\
\hline Yasu & Lower & Fish (Chub) & Nipponocypris temminckii & & 22.08 & 6.56 & & & 12.27 & -22.25 & 100.00 & \\
\hline Yasu & Upper & Fish (Trout) & Oncorhynchus masou ishikawae & & 12.65 & -1.82 & 78.93 & 2.83 & 3.11 & -21.93 & 56.57 & 2.87 \\
\hline Yasu & Upper & Fish (Minnow) & Rhynchocypris oxycephalus jouyi & & 12.58 & 0.86 & 59.50 & 2.86 & 4.23 & -24.86 & 28.37 & 3.21 \\
\hline Ado & Upper & Fish (Minnow) & Rhynchocypris oxycephalus jouyi & & 15.64 & 1.30 & 81.29 & 2.90 & 7.09 & -19.77 & 124.56 & \\
\hline Yasu & Upper & Crane fly & Tipulidae spp. & Other invertebrates & 12.03 & 1.81 & 68.73 & 2.55 & -0.35 & -21.43 & 57.22 & 1.57 \\
\hline Ado & Lower & Crane fly & Tipulidae spp. & Other invertebrates & 13.27 & 1.78 & 82.94 & 2.13 & -1.28 & -18.43 & 162.64 & \\
\hline Ado & Upper & Crane fly & Tipulidae spp. & Other invertebrates & 12.94 & 3.06 & 66.41 & 2.59 & 5.65 & -22.29 & 91.77 & 2.52 \\
\hline Ado & Lower & Crane fly & Tipulidae spp. & Other invertebrates & 15.22 & 4.22 & 62.19 & 2.64 & 7.14 & -21.08 & 64.20 & 2.74 \\
\hline Ado & Upper & Dobson fly & Protohermes grandis & Predator & 15.12 & 3.59 & 66.78 & 2.59 & 4.18 & -20.84 & 76.50 & 2.09 \\
\hline Ado & Upper & Dobson fly & Protohermes grandis & Predator & 12.37 & 2.22 & 76.93 & 2.24 & & & & \\
\hline Ado & Upper & Dobson fly & Protohermes grandis & Predator & 12.97 & 1.14 & 86.10 & 2.32 & & & & \\
\hline Ado & Upper & Dobson fly & Protohermes grandis & Predator & 11.39 & 0.70 & 89.03 & 2.12 & & & & \\
\hline Ado & Upper & Dobson fly & Protohermes grandis & Predator & 10.37 & -0.18 & 90.82 & 2.22 & 3.46 & -22.15 & 101.56 & \\
\hline Yasu & Upper & Caddisfly & Hydropsychidae spp. & Filter feeder & 6.72 & -1.28 & 90.17 & 1.86 & 9.63 & -26.50 & 8.28 & 4.46 \\
\hline Ado & Upper & Caddisfly & Hydropsychidae spp. & Filter feeder & 12.79 & 0.66 & 89.98 & 2.30 & 9.12 & -23.62 & 41.93 & 3.71 \\
\hline Ado & Upper & Caddisfly & Hydropsychidae spp. & Filter feeder & 13.07 & 0.72 & 89.61 & 2.33 & 9.22 & -21.93 & 56.50 & 3.67 \\
\hline
\end{tabular}


Table A4 (continued).

\begin{tabular}{|c|c|c|c|c|c|c|c|c|c|c|c|c|}
\hline \multirow[b]{2}{*}{ River } & \multirow[b]{2}{*}{ Site } & \multirow[b]{2}{*}{ Specimen } & \multirow[b]{2}{*}{ Scientific name } & \multirow[b]{2}{*}{ FFG } & \multicolumn{4}{|c|}{ SIAA } & \multicolumn{4}{|c|}{ Bulk } \\
\hline & & & & & $\begin{array}{l}\delta^{15} \mathrm{~N}_{\mathrm{Glu}} \\
(\%)\end{array}$ & $\begin{array}{l}\delta^{15} \mathrm{~N}_{\text {Phe }} \\
(\%)\end{array}$ & $\begin{array}{l}\text { Periphyton contribution } \\
\text { (\%) }\end{array}$ & $\begin{array}{l}\text { Trophic } \\
\text { position }\end{array}$ & $\begin{array}{l}\delta^{15} \mathrm{~N}_{\text {Bulk }} \\
(\%)\end{array}$ & $\begin{array}{l}\delta^{13} \mathrm{C}_{\text {Bulk }} \\
(\%)\end{array}$ & $\begin{array}{l}\text { Periphyton contribution } \\
\text { (\%) }\end{array}$ & $\begin{array}{l}\text { Trophic } \\
\text { position }\end{array}$ \\
\hline Yasu & Lower & Caddisfly & Stenopsyche marmorata & Filter feeder & 18.85 & 8.26 & & & 3.46 & -17.48 & 100.00 & \\
\hline Yasu & Lower & Caddisfly & Stenopsyche marmorata & Filter feeder & 19.95 & 7.66 & & & 3.55 & -21.31 & 100.00 & \\
\hline Ado & Lower & Caddisfly & Hydropsychidae spp. & Filter feeder & 13.47 & 1.24 & 87.32 & 2.14 & 3.05 & -21.79 & 102.07 & \\
\hline Ado & Lower & Caddisfly & Hydropsychidae spp. & Filter feeder & 13.18 & 1.96 & 81.45 & 2.13 & 2.97 & -22.59 & 91.21 & 1.33 \\
\hline Ado & Lower & Caddisfly & Stenopsyche marmorata & Filter feeder & 13.48 & 1.76 & 83.18 & 2.16 & 3.36 & -22.95 & 85.06 & 1.49 \\
\hline Yasu & Upper & Caddisfly & Hydropsychidae spp. & Filter feeder & 7.05 & -3.11 & 86.31 & 2.12 & -0.78 & -22.81 & 56.87 & 1.73 \\
\hline Ado & Upper & Caddisfly & Hydropsychidae spp. & Filter feeder & 12.82 & -2.78 & 112.12 & & 3.36 & -22.93 & 90.24 & 1.85 \\
\hline Yasu & Lower & Caddisfly & Hydropsychidae spp. & Filter feeder & 12.23 & 2.51 & 104.64 & & 6.38 & -22.62 & 49.52 & 2.10 \\
\hline Ado & Lower & Caddisfly & Hydropsychidae spp. & Filter feeder & 11.70 & 0.73 & 89.03 & 2.18 & 5.26 & -23.05 & 49.22 & 2.26 \\
\hline Yasu & Upper & Caddisfly & Goerodes spp. & Shredder & 5.06 & 8.91 & 12.22 & 1.76 & & & & \\
\hline Yasu & Upper & Caddisfly & Goerodes spp. & Shredder & 4.37 & 6.54 & 15.26 & 1.90 & -0.86 & -26.46 & 24.89 & 1.72 \\
\hline Yasu & Upper & Caddisfly & Goerodes spp. & Shredder & 4.87 & 7.55 & 8.06 & 1.98 & -1.07 & -26.27 & 26.98 & 1.66 \\
\hline Ado & Upper & Caddisfly & Goerodes spp. & Shredder & 7.68 & 5.36 & 46.35 & 1.97 & 1.19 & -26.81 & 39.72 & 1.50 \\
\hline Yasu & Lower & Caddisfly & Goerodes spp. & Shredder & 14.97 & 10.48 & 37.05 & 2.47 & 7.66 & -27.63 & 1.50 & 2.91 \\
\hline Yasu & Upper & C3 Litter & & & -1.15 & 10.21 & 0.00 & 1.00 & -2.10 & -30.51 & & \\
\hline Ado & Upper & C3 Litter & & & 2.56 & 11.06 & 0.00 & 1.00 & -0.72 & -30.71 & & \\
\hline Ado & Lower & C3 Litter & & & 1.14 & 11.50 & 0.00 & 1.00 & -0.26 & -29.94 & & \\
\hline Yasu & Upper & C3 Litter & & & -3.04 & 8.27 & 0.00 & 1.00 & -3.35 & -29.86 & & \\
\hline Ado & Upper & C3 Litter & & & -0.90 & 10.84 & 0.00 & 1.00 & -1.26 & -30.03 & & \\
\hline Yasu & Lower & C3 Litter & & & 1.88 & 14.11 & 0.00 & 1.00 & 1.13 & -29.33 & & \\
\hline Ado & Lower & C3 Litter & & & 1.59 & 11.22 & 0.00 & 1.00 & 0.15 & -29.27 & & \\
\hline Yasu & Lower & POM & & & 14.03 & 6.66 & & & 7.21 & -24.96 & & \\
\hline
\end{tabular}




\section{Figure legends}

\section{Fig. A1.}

Study sites draining the Lake Biwa basin, central Japan. Areas surrounded by lines indicate watersheds of the main stems of the Yasu and Ado rivers. Open and solid stars in the Yasu and Ado rivers indicate the upper and lower sites studied, respectively

\section{Fig. A2.}

Landscapes of the study sites 


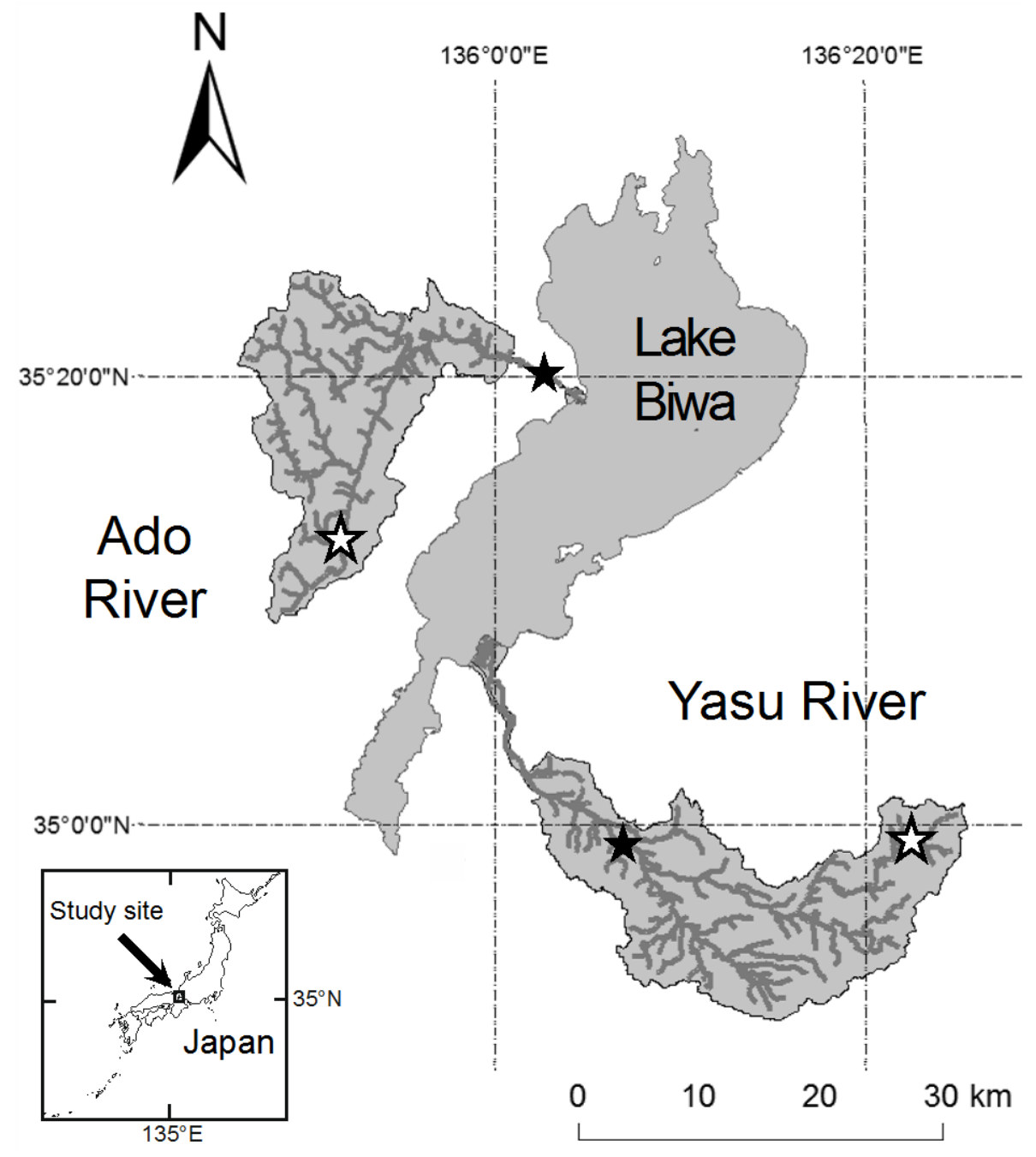

Figure A1 


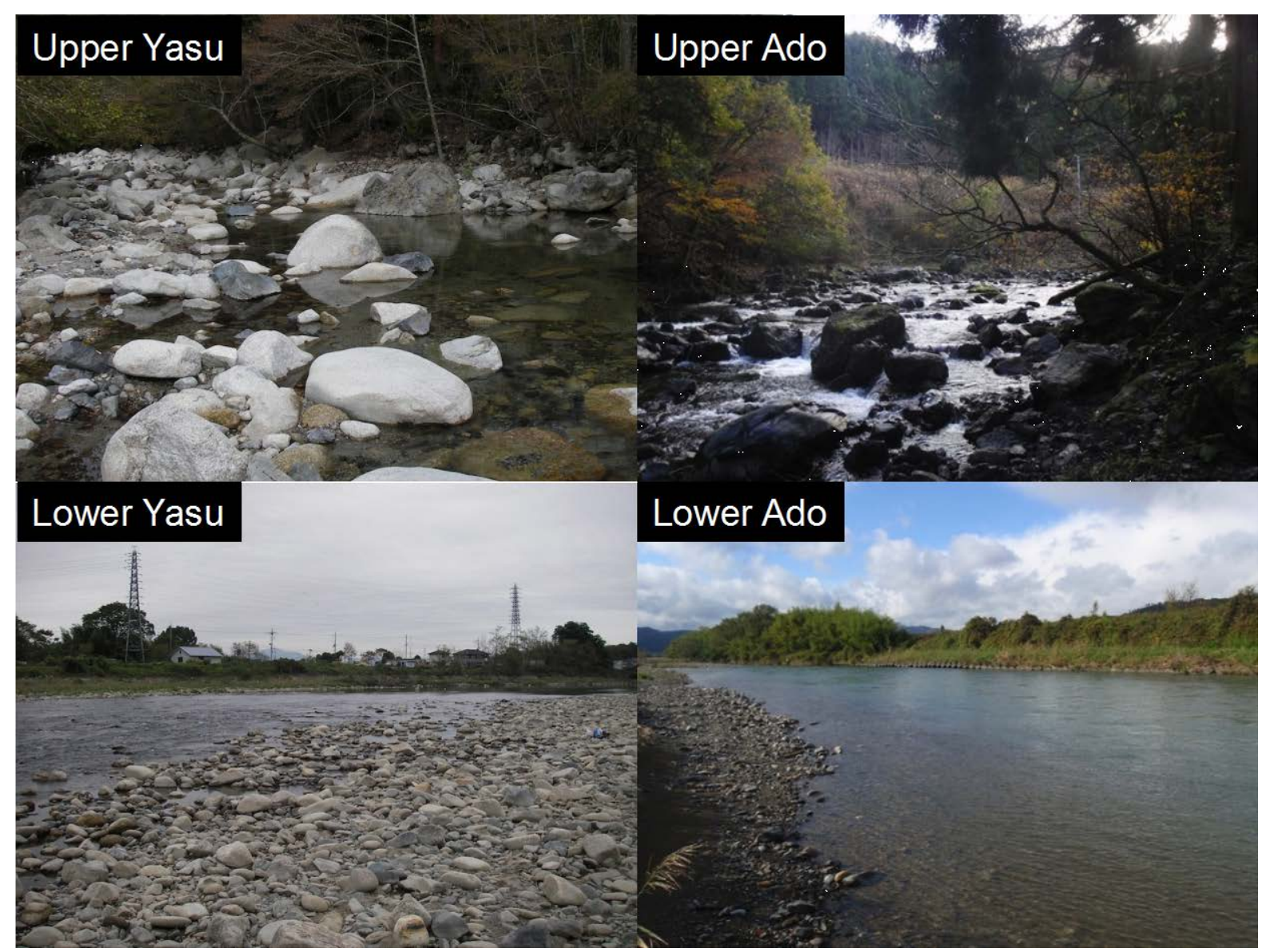

Figure A2 